\title{
Modern Slavery Disclosure Regulation and Global Supply Chains: Insights from Stakeholder Narratives on the UK Modern Slavery Act
}

\author{
Muhammad Azizul Islam ${ }^{1} \cdot$ Chris J. Van Staden ${ }^{2}$
}

Received: 9 September 2020 / Accepted: 17 June 2021 / Published online: 6 July 2021

(c) The Author(s) 2021

\begin{abstract}
The purpose of this article is to problematise a particular social transparency and disclosure regulation in the UK, that transcend national boundaries in order to control (modern) slavery in supply chains operating in the developing world. Drawing on notions from the regulatory and sociology literature, i.e. transparency and normativity, and by interviewing anti-slavery activists and experts, this study explores the limitations of the disclosure and transparency requirements of the UK Modern Slavery Act and, more specifically, how anti-slavery activists experience and interpret the new regulations and the regulators' implementation of the regulation. This research found limited confidence among anti-slavery activists regarding the Act's call for transparency in relation to the elimination of slavery from global supply chains. The research also found that the limits of the transparency provisions within the Act appear to hinder the attainment of normativity. This study provides new and unique insights into the critical role that social activists play in exposing the lack of corporate transparency and failures of responsibility to protect workers within global supply chains.
\end{abstract}

Keywords Developing nations · Supply chains · UK Modern Slavery Act $2015 \cdot$ Transparency · Normativity · Disclosures · Anti-slavery activists $\cdot$ Regulation $\cdot$ Societal stakeholders

\section{Introduction}

Over the past two decades, stakeholder concerns and ubiquitous public pressures have led to evolving forms of social and environmental disclosure and transparency regulations in different countries. This has attracted a growing body of research on the effect of social and environmental disclosure regulations on corporate disclosure and transparency practices (see, for example, Islam \& Van Staden, 2018; Birkey et al., 2018; Bebbington et al., 2012; Blacconiere \& Patten, 1994; Blacconiere \& Northcut, 1997; Chauvey et al., 2015; Larrinaga et al., 2002). Prior research mainly analysed disclosures (in annual reports, CSR/sustainability reports and websites) in response to regulation mandating disclosure. ${ }^{1}$ We extend this body of research by focussing on a new and important piece of regulation, the UK Modern

Muhammad Azizul Islam

azizul.islam@abdn.ac.uk

1 Accounting Discipline, Business School, University of Aberdeen, Aberdeen, UK

2 Department of Accounting, AUT Business School, Auckland University of Technology, Auckland, New Zealand
Slavery Act of 2015, and stakeholder narratives on its success or limitations in achieving transparent modern slavery disclosures and attaining normativity (i.e. being regarded as good and desirable). Identifying and documenting critical issues in regulation enacted to address a social problem like modern slavery is important in order to improve future regulatory direction/s to eliminate unethical practices like modern slavery from supply chains and society.

Modern slavery is an unethical practice (ILO and Walk Free Foundation, 2017; Blitz \& Simic, 2019) and its pervasive presence in global supply chains has attracted global criticism (Ansett \& Hantover, 2013; Arnold \& Hewison, 2005; Barrientos \& Smith, 2007; Hughes et al., 2007; Kasperkevic, 2016; Kelly, 2014). Major disasters, such as the Rana Plaza collapse in 2013 that killed more than 1100 workers in factories in Bangladesh that produced garments for western retailers, are indicative of weak moral and ethical standards applied by global retailers in their supply chains (Islam et al., 2021). This has led to new forms of regulation (such as the UK Modern Slavery Act of 2015; the

\footnotetext{
${ }^{1}$ In particular, scholars have mainly focussed on the impact of particular regulations on corporate disclosures, without necessarily connecting 'disclosure' with 'transparency'.
} 
US Dodd-Frank Act's conflict mineral reporting rules, the California Transparency in Supply Chains Act, and the Australian Modern Slavery Act of 2018) that attracted significant academic and social activist attention (Roshitsh, 2021; Sobik, 2020; Rogerson et al., 2020; Hansard, 2019; LeBaron \& Rühmkorf, 2019; Blitz \& Simic, 2019; Stevenson \& Cole, 2018; Christ \& Burritt, 2018; Birkey et al., 2018; Islam \& Van Staden, 2018; The Guardian, 2015; New, 2015; Crane, 2013; Gold et al., 2015). In relation to the UK Modern Slavery Act, while the Act is heralded to create transparency in relation to factory working conditions within global supply chains, there are concerns among academics and anti-slavery activists about the Act's limitations and resulting effectiveness (The Guardian, 2015; Hansard, 2019; LeBaron \& Rühmkorf, 2019; Stevenson \& Cole, 2018).

Drawing on notions of supply chain transparency (EgelsZandén et al., 2015; Gold \& Heikkurinen, 2018) and regulatory normativity (Ewick \& Silbey, 2003; Gray \& Silbey, 2014) and the literature on counter-accounts/narratives (Islam et al., 2021; Semeen \& Islam, 2021; Neu et al., 2020; Lehman et al., 2016; Vinnari and Laine 2017; Gallhofer et al., 2006), we use interviews and publicly available reports and documents to provide an insight into the limitations of the UK Modern Slavery Act. Previous research examined the normativity of social and environmental disclosure regulations by documenting the extent of corporate disclosure in compliance with the regulations (see, for example, Birkey et al., 2018; Chauvey et al., 2015). Our focus differs from the previous research in that we draw on the sociology literature on normativity (Ewick \& Silbey, 2003; Gray \& Silbey, 2014) to examine the content and quality of the UK Modern Slavery Act rather than focussing on the Act's impact on corporate disclosures. We do this by obtaining stakeholder views and narratives on the content and quality of the Act to assess the achievement of transparency regarding modern slavery in global supply chains and the attainment of normativity for the Act within the public domain. By focussing on the views of anti-slavery activists and experts, we problematise a particular social transparency and disclosure regulation in the UK, that transcend national boundaries in order to control (modern) slavery in supply chains operating in the developing world. Our focus on anti-slavery activists is very pertinent, since anti-slavery activists not only played an important role in bringing about the UK Modern Slavery Act of 2015, they were also responsible for the inclusion of Section 54 on transparency to the legislation, as we discuss in the next part. They also represent society, which is arguable the most impacted by modern slavery as they can be the victims of this practice. Their views on whether the Act did, in fact, achieve its transparency aim and attained normativity are therefore topical and important.

We find that the interviewees expressed concerns (or reservations) about the Act achieving transparency, for respecting the public interest, and for attaining normativity. Based on the notions of normativity (Ewick \& Silbey, 2003; Gray \& Silbey, 2014) and supply chain transparency (EgelsZandén et al., 2015; Gold \& Heikkurinen, 2018), we find that while Act's minimum disclosure provisions did not lead to the achievement of transparency, this may also hamper the Act's normativity. Improved transparency and normativity could result from the roles anti-slavery campaign groups can play through the surveillance of corporate compliance with the Act and their ability to trace the source of manufacturing within supply chains. Our study provides new insights into the critical role of anti-slavery activists and NGOs in understanding the limitations of a particular disclosure regulation to create transparency and attain normativity, as well as the roles these activists could play in holding regulators and companies responsible for their modern slavery-related unethical practices in global supply chains. We contribute to the interdisciplinary literature on transparency and regulatory normativity by highlighting anti-slavery activists' critical evaluations of a new transparency and disclosure regulation with regards to the elimination of modern slavery within global supply chains. We also contribute to the counter-account/narrative literature (see, for example, Semeen \& Islam, 2021; Islam et al., 2018, 2021) that shows that NGOs, activists and social movement organisations are crucial actors in exposing the lack of corporate transparency and accountability, and failures of responsibility to protect workers within the global supply chains.

This paper is organised as follows. The Sect. "The UK Modern Slavery Act of 2015 and its Provisions for Global Supply Chains" provides a background for the UK Modern Slavery Act. The Sect. "Transparency and Normativity" describes the theoretical framework of this research. The Sect. "Research methods" explains the research methods, while the Sect. "Findings and analysis" sets out the findings and the analysis of the interviews conducted. The Sect. "Conclusion" provides a conclusion.

\section{The UK Modern Slavery Act of 2015 and its Provisions for Global Supply Chains}

Historically, slavery meant owning persons as legal property and principles of property law were applied to human beings (Allain, 2017). This meant that people were bought and sold as their owners saw fit and were made to work hard under often inhumane conditions. Although we do not see much of this form of slavery nowadays, different forms of slavery have emerged with globalisation. As a broad term, modern slavery encompasses unethical practices and may take many forms, among them unpaid labour, human trafficking, child or forced labour, and forced marriages. In 2016, it was estimated that over 40.3 million people worldwide were 
enmeshed in some form of modern slavery, that is, there were 5.4 victims of modern slavery for every 1000 people in the world (ILO and Walk Free Foundation, 2017). In the United Kingdom, on any given day in 2016, 136,000 people lived in modern slavery conditions, that is, 2.1 victims for every 1000 people in the country (The Global Slavery Index, 2018). However, forced labour is the main form of modern slavery within global supply chains and 25 million people are in forced labour worldwide (ILO and Walk Free Foundation, 2017). With regards to global supply chains, there is a ubiquitous public and academic discourse suggesting that the use of forced labour facilitates lower labour costs and boosts the revenues of multinational retailers and suppliers (Chalmers, 2013; FEE, 2017; Oxfam, 2018) and this, in turn, raise problematic issues regarding the ethical standing of both retailers and suppliers (Islam et al., 2021). ${ }^{2}$

Modern slavery issues are gaining significant public and academic attention because high-profile human rights crises are emerging in global supply chains (Christ \& Burritt, 2018; Crane, 2013; Gadd \& Broad, 2018; Gold et al., 2015; Islam et al., 2018, 2021; Landau \& Marshall, 2018; Mehra \& Shay, 2016; New, 2015; Turner, 2016), for example, the 2013 Rana Plaza disaster in Bangladesh, and because new forms of modern slavery regulation are evolving to regulate MNCs and their suppliers in the developing world. Transparency and disclosure regulations such as the California Transparency in Supply Chains Act of 2010 (CTSCA), the US Dodd-Frank Act's conflict minerals rules, the UK Modern Slavery Act 2015, the French Duty of Vigilance Law 2017, The Netherlands Due Diligence on Child Labour Act 2017 and the Australian Modern Slavery Act 2018, have implications for companies operating in the West as well as their suppliers in the developing world. What is new in these regulations is that they require companies to provide transparency statements or disclosures on tackling modern slavery and forced labour arising from their business operations. While research on corporate transparency, in general,

\footnotetext{
${ }^{2}$ We acknowledge that defining modern slavery and unethical practices are complex phenomena and debatable. In particular, there are complex boundaries to determine ethical practices within supply chains located across developing and developed nations. What can be regarded as acceptable practice in the developing world, may not be regarded as ethical in many developed nations. For example, child labour is unethical in the western world, but the dismissal of already employed child workers in many parts of the developing world could have immediate and devastating impacts on the child workers and their families whose survival depends on the income earned by these children. The unemployment or immediate dismissal may lead to poverty conditions and result in increased (child) prostitution. While employment of child labour is not ethical in the UK, EU, USA or to the international community, such practice can be acceptable (even from an ethical perspective), in many parts of developing world where unemployment of children threatens their fundamental right to survival (Rahman et al., 1999).
}

is not new (see Bushman et al., 2004 for financial transparency and Islam \& Van Staden, 2018 for social transparency), research investigating the extent to which particular transparency regulations is perceived to create transparency and accountability is sparse. While voluntary disclosure by companies is increasing over time (see, for example, KPMG, 2008, 2017), disclosure practices as part of transparency in response to regulation are weak (Birkey et al., 2018; Chauvey et al., 2015). This is echoed in more recent industry research, which shows that initial modern slavery disclosures in response to the UK Modern Slavery Act 2015 are low (Steiner-Dicks, 2019). While it is still too early to gain a full understanding of how companies are responding to the UK Modern Slavery Act and whether this will bring long-term social justice, our research contributes to critical work on the limitations of modern slavery transparency regulations.

Section 54 of the UK Modern Slavery Act $2015^{3}$ requires companies with an annual turnover of $£ 36$ million or more to publish a modern slavery statement in relation to its supply chains every year on its website. Companies covered by this section need to disclose the following information (Home Office, 2015, p. 12):

- Their organisational structure, business, and supply chains;

- Their policies in relation to slavery and human trafficking;

- Their due diligence processes in relation to slavery and human trafficking in their business and supply chains;

- The parts of their business and supply chains where the risk of slavery and/or human trafficking arises, and the steps they have taken to assess and manage the risk;

- Their effectiveness in ensuring that slavery and human trafficking are not taking place in their business or supply chains, measured against such performance indicators as they consider appropriate;

- The training and capacity-building about slavery and human trafficking made available to their staff.

Section 54 was not originally included in the act. This section was brought in at the amendment stage following civil society campaigns, which led to the 'last minute' attention given to supply chain disclosures with minimum compliance requirements (or minimum disclosure requirements) (The Guardian, 2015; LeBaron \& Rühmkorf, 2019). The act was not applicable to the public sector. There was an attempt

\footnotetext{
3 As we are interested to explore how a new form of regulation creates transparency in global supply chains, we find Sect. 54 of the UK Modern Slavery Act 2015 the most relevant for our study. The Act also have a number of other provisions (including human trafficking offences and the creation of an independent anti-slavery commissioner) focussing more on the local context (i.e. the UK context).
} 
to introduce draft disclosure for public sector supply chains, but that was lost in the legislative processes when the 2017 UK general election was called and has not subsequently been resurrected (Hansard, 2019).

The minimum compliance requirements under Section 54 do not specify what a modern slavery statement must include in terms of disclosures or how it should be structured. It provides a non-exhaustive list of information that may be included (Home Office, 2015). While the Act indicates that organisations should, as a minimum, describe the main actions they have taken during the financial year to deal with modern slavery risks in their supply chains and their own business (Home Office, 2015), it emphasises that these organisations should present a detailed picture of all the steps they have taken to address and remedy modern slavery, and the effectiveness of all such steps (The Barrister, 2019). The Act's requirements appear quite broad and setting a minimum disclosure requirement leaves discretion to companies over the interpretation and implementation of the Act. As a result, there are flexibility and opportunities for different approaches to the level of desired disclosure and the degree of coordination within and between organisations. Moreover, while knowledge of how transparency reporting practices are set or regulated is sparse, a critical question relates to the degree to which regulated organisations have digested the Act so far, where the boundaries of implementation may be, and the effectiveness of the Act. At the same time, earlier research has found a limited response and low disclosure (Stevenson \& Cole, 2018), and many companies have not published the required statements (Hansard, 2019). While there is the public and academic discourse on the limitations of the Act for protecting the public interest (The Guardian, 2015; Hansard, 2019; LeBaron \& Rühmkorf, 2019; Roshitsh, 2021; Sobik, 2020; Stevenson \& Cole, 2018), we specifically focus on supply chain transparency and the Act's ability to become normative (i.e. being regarded as good or desirable or permissible). We argue that anti-slavery campaign groups and civil society organisations are in a better position to provide narratives about the limitations of the act. In other words, in line with the counter-account literature focussing on working conditions within global supply chains (Islam et al., 2021, 2018; Semeen \& Islam, 2021), we problematise the disclosure regulations through counternarratives by anti-slavery campaign organisations. While the existing literature is rich in terms of exploring counternarratives/accounts on different social and environmental issues (see, for example, Semeen \& Islam, 2021; Neu et al., 2020; Lehman et al., 2016), the issues of modern slavery are under-researched.

Regulations are usually introduced in the name of protecting the 'public interest' or the welfare of the general public. ${ }^{4}$ However, there is a broader concern that the regulators' purpose of protecting the public interest is sometimes unclear, because it is unclear how the public interest should be defined and how it could be protected in practice. In particular, the broader tension highlighted in the critical regulation literature is that a particular regulation could be thwarted by regulatory capture. Regulatory capture results in regulation that gains support from different constituencies but may in fact not be in the public's best interest (Baudot et al., 2017). History provides many examples of regulators prioritising the interest of the regulated who have power and wealth over that of the general public (Wilson et al., 2018). Accordingly, it can be argued that if certain powerful groups or multinational companies (MNCs) capture the regulatory process or the implementation of the regulation, policies or regulations like the Modern Slavery Act 2015 will probably be that much less effective in changing the way that organisations operate, i.e. the Act may not lead to the required or expected transparency about modern slavery and may not achieve normativity.

\section{Transparency and Normativity}

Previous research investigated the impact of regulations on corporate transparency and disclosures with regards to different social and environmental issues, using market theories (such as agency theory, Blacconiere \& Northcut, 1997; Blacconiere \& Patten, 1994) and non-market theories (i.e. legitimacy perspectives, Islam \& McPhail, 2011; Larrinaga et al., 2002) to explain disclosures. In this paper, we use a non-market theoretical construct, which includes notions of transparency (Egels-Zandén \& Hansson, 2016; EgelsZandén et al., 2015; Gardner et al., 2019) and regulatory normativity (Ewick \& Silbey, 1998, 2003) to analyse the limitations of transparency required under the UK Modern Slavery Act. Each component of the theoretical framework for this research is discussed below.

\section{The Notion of Supply Chain Transparency}

A wide range of social science studies ranging from communication, business and accounting, development studies, ethics, law, political science to public administration have proliferated the concept of transparency (i.e. Islam \& Van

\footnotetext{
${ }^{4}$ Historically, regulation, in the name of protecting the welfare of the general people, is typically enacted after a (financial, social or environmental) crisis (Harnay \& Scialom, 2016). For example, following Enron's collapse, the US government introduced the Sarbanes-Oxley Act to protect shareholders by requiring companies to be more transparent about their internal controls (Coates, 2007). And following the 2008 financial crisis, the governments of many countries brought in legislation to increase the monitoring of banks and thereby to protect the public interest (Kim \& Muldoon, 2015).
} 
Staden, 2018; Qian et al., 2015; Gardner et al., 2019; Gold \& Heikkurinen, 2018; Egels-Zandén et al., 2015; Berliner, 2014; Fung et al., 2007; Hollyer et al., 2011; Meijer, 2009; Bauhr \& Nasiritousi, 2012; Finel \& Lord, 1999, 2007; Grigorescu, 2003; Rosenfeld \& Denice, 2015; Fenster, 2010; Pinto, 2009; Bernstein, 2017; Buell et al., 2017; Zhu, 2004) and our review of these studies suggest that transparency is a ubiquitous, relational concept. As a relational concept, transparency can relate to financial concerns (see, for example, Qian et al., 2015; Barth \& Schipper, 2008), non-financial and/or social concerns (Islam \& Van Staden, 2018; Quaak et al., 2007), political concerns (Heard-Lauréote, 2007) and so on. In the business literature, transparency studies can be broadly classified into financial and social transparency. While financial transparency, in general, relates to the disclosure of financial and market information by corporations (Barth \& Schipper, 2008), social transparency relates to the disclosure of social responsibility information by corporations (Islam \& Van Staden, 2018). In this paper, we focus on supply chain transparency-a form of social transparency mostly covered in the general business literature (Egels-Zandén et al., 2015; Gardner et al., 2019; Gold \& Heikkurinen, 2018; Islam \& Van Staden, 2018; Steinfield et al., 2011). We specifically focus on supply chain-related transparency provisions within the UK Modern Slavery Act.

Previous research that focussed on transparency within global supply chains, refers to corporate transparency as the disclosure of specific information, including the traceability of suppliers by providing the names and factory locations of suppliers involved in producing the organisation's products and the working conditions associated with these suppliers (Egels-Zandén et al., 2015; Gardner et al., 2019). Arguably 'traceability' of information is one of the critical ways to define the limits of transparency. That is, to be traceable, a member of the broader community (including consumers) should be able to easily trace where (which factory) and how a particular product was manufactured (this includes production, transport, and processing systems). Traceability of information provides transparency around factory operations and factory disclosures, and this could result in positive changes in the way that organisations manage their supply chain labour practices (Egels-Zandén \& Hansson, 2016). However, there is a view that disclosing this information generates risks and expenses for a corporation if its competitors do not disclose similar information (Egels-Zandén \& Hansson, 2016). 'For that reason, mandatory factory disclosure would be justified as a measure to level the playing field and to help ensure that those corporations who do the least to police their supply chain labor practices are not rewarded by their ability to remain hidden in the shadows' (Doorey, 2011, p. 601).

By focussing on global supply chains, Gold and Heikkurinen (2018) argue that while past research has claimed that transparency leads to responsibility and thus drives sustainable changes in business organisations' practices, this is not the case within global supply chains. They provide a theoretical framework that shows that claims (calls) for corporate transparency, as a means to increase the responsibility of MNCs for their supply chains, have proved inadequate. Gold and Heikkurinen's (2018) insights are consistent with prior critical accounting literature that highlighted the difficulty of providing a nuanced contextualised understanding of transparency through corporate disclosures (see, for example, Coslor, 2016; Roberts, 2009). While these authors did not examine transparency regulations, given the emerging trend to regulate for transparency across countries, we are particularly interested in the UK's call for transparency in supply chains via the Modern Slavery Act 2015. Gold and Heikkurinen's (2018) findings could be relevant for a situation where a regulator fails to achieve its regulatory objective of ensuring corporate transparency. We argue that there is a significant research gap, a need to address how regulations such as the UK Modern Slavery Act further the idea of transparency in an attempt to eliminate (modern) slavery from global supply chains. We argue that understanding this kind of social transparency is important, as there are situations or contexts (including regulatory contexts) in which compromising transparency for protecting corporate self-interest can be regarded as unethical and can have critical consequences for vulnerable stakeholders, including workers in global supply chains operating in developing countries.

We take a stakeholder perspective using the narratives (interviews) of anti-slavery activists which can be regarded as counter-narratives and we, therefore, refer to the counteraccount literature to inform and motivate our approach. The literature on counter/alternative accounts argues that counter-narratives are the alternative representations or accounts of organisations and regulatory bodies, produced by NGOs and social movement organisations as a part of their actions against social inequality and irresponsibility (Vinnari \& Laine, 2017; Gallhofer et al., 2006; Lehman et al., 2016; Semeen \& Islam, 2021; Islam et al., 2018, 2021). Counteraccounts are often mobilised to make heard the voices of vulnerable groups by exposing social inequalities perpetuated by the elites (Gallhofer et al., 2006; Vinnari \& Laine, 2017). The counter-account literature that focuses on global supply chains (i.e. Semeen \& Islam, 2021; Islam et al., 2018, 2021) offers the insight that NGOs and activists are crucial actors in exposing problems with corporate transparency and accountability, and the failure to protect workers within global supply chains. Accordingly, we argue that the narratives of anti-slavery activists are very important to expose the problems and issues hindering the achievement of transparency with regards to modern slavery, and these narratives are essential catalysts for future change. 


\section{The Notion of the Normativity of Regulation}

Drawing on the broader social science literature on the normativity of regulation (Baier, 2016; Chelli et al., 2018; Ewick \& Silbey, 1998, 2003; Jackson, 2018; Schmidt \& Rakoczy, 2018), we examine the disclosure provisions of the UK Modern Slavery Act. Normativity describes moral bases or values of regulation and regulatory compliance. Ewick and Silbey (1998) suggest that normativity provides a dimension of people's belief about how participants (both professional and laypeople) should act in legal interactions. It also specifies why regulation should, or should not, be invoked, obeyed, or resisted. In short, 'references to normativity describe the moral bases of legality' (Ewick \& Silbey, 1998, p.83). When people repeatedly refer to regulation as being impartial and objective, they view this as normative. "Impartiality corresponds to the absence of a historical, biographical and socially located, and thus "interested", self' (Ewick \& Silbey, 2003, p. 1342). The notion of normativity may be further transformed from a normative claim about how things should be done to a factual description of how the real-world works (Ewick \& Silbey, 2003). In other words, the idea of normativity posits that, other than the normative claim, those taking part in legal interactions provide the understanding of how actors mobilise the law and evaluate legal processes and their invocations, and even how they use the law outside formal legal settings. Accordingly, the normativity of regulation is about more than just the core legal phenomena with interest in the effectiveness of law or consequences of regulations (Sarat \& Kearns, 1993) but also involves the evaluation of the due processes above and beyond the formal legal setting. Normativity, therefore, suggests that regulation is regarded as good or desirable.

There are different reasons why regulators face a challenge in gaining normative status for regulation. Regulators can themselves be obstacles or barriers to the acceptance of regulations if they lack sufficient expertise to understand the work processes that they are regulating (Gray \& Silbey, 2014). This may manifest through a lack of monitoring or expertise in auditing compliance with the regulations or relate to other reasons. The regulators may also face challenges because the regulations lack impartiality (in particular during the implementation of the law). Ewick and Silbey (2003, p. 1347) describe the antithesis to normativity in the following way:

'...other accounts described the arbitrariness of legal authority, its unpredictability, and raw power. Here law was simply the power of the powerful. Rather than seeing legal authority as derived from moral principles, objective reasoning, or regulated processes that legitimated its power, these stories reversed the direction of legitimation, describing power as producing the normative grounds upon which legality is exercised. Might, in these stories, makes right'.

This statement illustrates a primary obstacle to the normativity of regulations, arbitrariness, unpredictability, or uncertainty of legal authority. At the same time, another major obstacle to normativity is the abuse of power in the regulatory process. Through the process of regulating, or of gaining legitimation for regulation, powerful groups may gain power by disregarding the moral principles underlying the regulations.

While the notion of the normativity of regulation contains the moral bases for the legality, the moral basis of the UK Modern Slavery Act is in its aim, which is to eliminate modern slavery practices. Nevertheless, there is a risk that power imbalances may erode the Act's normativity. While the limits of transparency can be assessed by exploring the normativity of the regulation, the issue remains under-researched. While normativity concerns the values underlying regulations, we assess the regulatory value by exploring the views of the broader community, including anti-slavery campaign groups, in responding to the regulations.

Prior research (e.g. Buhmann, 2011; Bebbington et al., 2012; Manacorda, 2014; Chauvey et al., 2015; Acerete et al., 2019; Manacorda, 2014; Birkey et al., 2018; Senn \& Giordano-Spring, 2020; Brusca et al., 2018; Chelli et al., 2018 - summarised in Table 1), focuses on different regulations ranging from country-level environmental reporting laws and CSR, to public sector accountability and reporting standards, used different methods ranging from content analysis, reviews, discourse analysis to interviews, to investigate the normativity of regulations. What this research reveals is that, in general, social and environmental disclosure regulations have an impact on normativity. Chauvey et al. (2015) and Chelli et al. (2018) found that companies in certain countries, over time, disclosed high levels of information complying with the regulatory disclosure requirements resulting in high levels of normativity. Birkey et al. (2018) argued that during the early stages of disclosure regulation, attainment of normativity by the concerned companies appeared to be low. A few studies (see, for example, Chauvey et al., 2015) tried to separate the attainment of an act's normativity from the quality of disclosure and found that while a level of normativity may be attained, disclosure quality is not high and therefore, the act's goals of increased transparency may remain unmet.

While prior disclosure research examined normativity of particular disclosure regulations by documenting the extent of corporate disclosure in compliance with the regulations, in this paper, we examine the attainment of the normativity of a disclosure regulation, the UK Modern Slavery Act, in the public domain, using stakeholder narratives. Our focus on stakeholder narratives is different from prior quantitative 


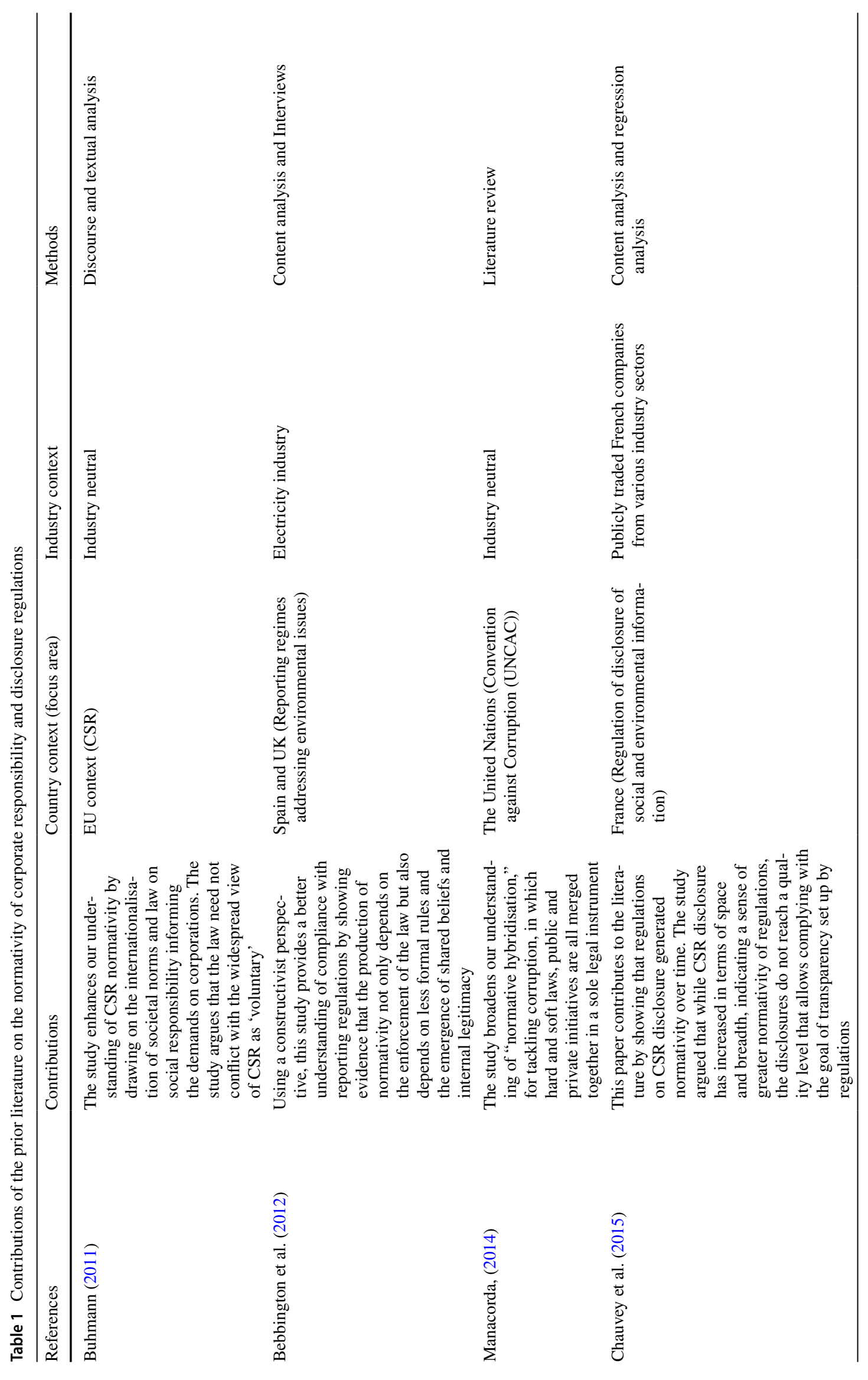




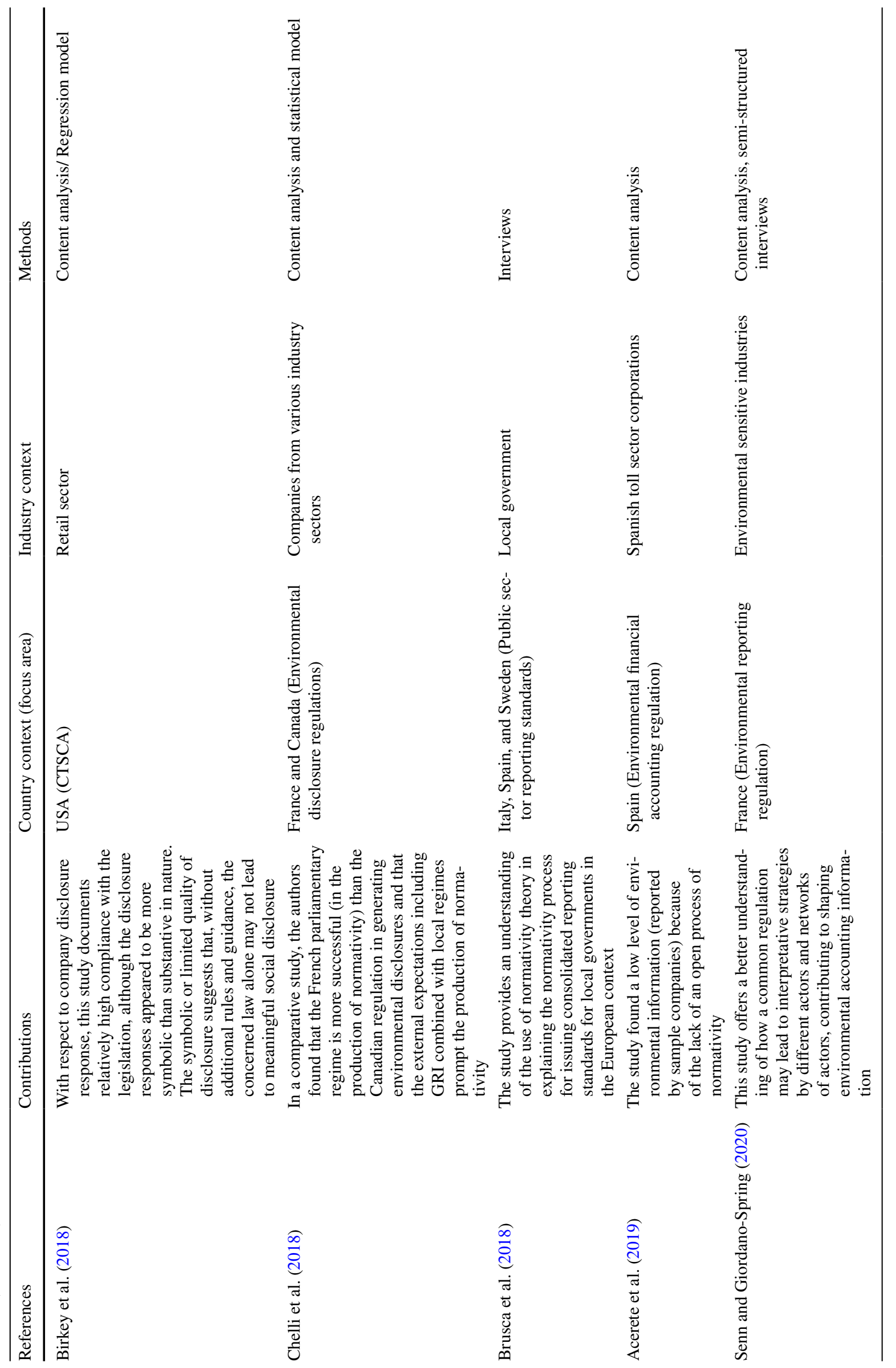


studies (see, for example, Chauvey et al., 2015; Chelli et al., 2018; Birkey et al., 2018) on the normativity of social and environmental disclosure regulations and qualitative (interview-based) studies (Bebbington et al., 2012; Senn \& Giordano-Spring, 2020) that documented the views of corporate managers and industry representatives and offered an understanding of internal (managerial) perspectives regarding the normativity of particular social and environmental disclosure regulations.

\section{Research Methods}

This study draws on interviews with anti-slavery campaign organisations and experts on corporate compliance with the UK Modern Slavery Act 2015. Fourteen interviews were conducted between September 2018 and February 2019: three interviews with corporate and industry managers, two interviews with ethical investment firms, seven with antislavery campaign organisations (ACOs) (code 1-7), one with a government representative and one with a policy adviser from a professional accounting body in the UK. ${ }^{5}$ The overall size and selection of the interviewees for this study is purposive. The overall strategy of interview data collection is often driven by the notion of data saturationsaturation is considered to have occurred when consecutive interviews do not provide the researcher with any new or additional insights (Malsch \& Salterio, 2016). In relation to the data collection strategy and the saturation point, Malsch and Salterio (2016) argue that the central aim/research question of the study is an important driver of the sample size. They also argue that the authors' expertise in the chosen topic, and research that uses more than one source of data collection (for example, interviews and documents) reduce the number of participants needed. Accordingly, as we mainly focussed on anti-slavery campaign organisations, we interviewed a sufficient number of activists from different anti-slavery campaign organisations, to meet our saturation point. We had three more interviews with people from anti-slavery campaign organisations, but these did not give us any additional insights (this approach is also consistent with Islam et al., 2018). Our extensive prior experience on the topic, interview methods and document analysis, and our use of multiple document sources in addition to interviews (see below) gives us confidence that our sample size is sufficient for our analysis. Interviews with other people (from government and industry) reflect mainly their official

\footnotetext{
5 While our extensive prior experience on the topic helped us to identify organisations working on modern slavery issues, a member of a global ethical trading campaign group was requested to identify suitable organisations that are active in the area of workers' rights and anti-slavery movements in global supply chains.
}

responses, which were already available in government/legal documents, corporate reports and industry documents. The interviewees are listed in the Appendix, keeping the interviewee identity confidential, in line with the research ethics guidelines.

Interviews were conducted with senior officials at various organisations. Interviewees were knowledgeable about modern slavery at different organisations working to eliminate modern slavery in the UK and its supply chains, and organisations experiencing higher levels of oversight and monitoring of corporate compliance with the Modern Slavery Act. The views of campaigners and experts represent a unique resource within the modern slavery context that has received relatively little research attention. The opinions documented via interviews with anti-slavery activists constitutes a form of counter-narrative, which were helpful to problematise the disclosure provisions of the modern slavery Act. Our selection of activists from anti-slavery campaign organisations as a producer of counter-narratives is purposive and consistent with the approach followed in critical and counter accounting research (Gallhofer et al., 2006; Semeen \& Islam, 2021; Lehman et al., 2016), that challenges the prevailing official and hegemonic position.

All people approached agreed to participate in telephone interviews and all were recorded with consent. The communication for appointments and consent was done via email. Interviews were transcribed within a week of the interview taking place. The interviews lasted from $30 \mathrm{~min}$ to one hour. While an interview guide was used, the questions were open-ended. Before commencing the interviews, the project was explained to each interviewee. As all interviews were conducted on a confidential basis, the observations reflected have not been attributed to a specific person or their organisation.

Across a wide range of research settings, we held informal communications and meetings (during workshops and conferences) with a large group of academics and industry experts on modern slavery, which helped this research to stay focussed on the research questions. While interviews were designed to probe the interpretations experts and activists of the implementation of the UK Modern Slavery Act, informal talks and meetings with a broader group of people helped the researchers to understand how the regulation works, how the work is done and what practitioners find satisfying and frustrating about it. This approach is consistent with sociology research (Gray \& Silbey, 2014) and we found this approach helped us gain a broader understanding of the UK Modern Slavery Act.

In particular, through interviews and informal communication, we learned how the participants interpret the governing rules and procedures (Gray \& Silbey, 2014). In line with this broader understanding, interviewees were explicitly asked to share their experience of whether the Act was 
achieving its primary purpose, to interpret the Act's limitations or boundaries, and to interpret its merits or demerits. While these questions were an indirect way to examine the theoretical constructs - transparency and normativity - we found this one of the best ways to support the research. Without this approach, we would not have been able to fully understand the limitations to the transparency and disclosure provisions within the Modern Slavery Act.

We analysed the data by drawing on Miles and Huberman's (1994) approach for conducting qualitative research. We followed the following key steps to process our data:

- All interview transcripts were read and coded in an attempt to interpret the data. All references to, and descriptions of, regulators and regulations by the people we interviewed were also collected and reviewed. The interviews helped us to analyse the implementation, transparency and normativity of the Modern Slavery Act during its early implementation and the associated mechanisms for UK companies sourcing products from overseas.

- We reviewed all available documents (selected from our extensive web-search) including three legal documents, 25 reports by NGOs and anti-slavery campaign organisations (five of these reports were sent to us by our interviewees from anti-slavery campaign organisations) and law firms, 20 news articles in the British news media and five modern slavery statements and corporate reports produced by our corporate interviewee organisations. This helped us to understand and code statements both by regulatory bodies, corporations and anti-slavery activist groups.

- By following a holistic coding system (Miles et al., 2014), we formed a comprehensive understanding of the overall contents of the interviews and documents. In our analysis, we mostly focussed on the statements and quotes from interviewees and we gave limited emphasis to the contents and statements from secondary documents as these were mostly overlapping with the interviews.

Analysis of the narratives, particularly those of anti-slavery activists, was performed in the light of the adopted theoretical concepts including the notion of transparency and the notion of normativity. Key interview questions and findings are presented in Table 2. Before interviewing people and analysing relevant reports and documents, we have formed a broad understanding of transparency and normativity. During the analysis, we refined and reframed our theoretical constructs to explain our data better. We adopted the theoretical framework discussed in Sect. 3 to analyse the opinions provided by experts and this helped us to uncover the various ways in which the interviewees express and interpret their relationships with the Modern Slavery Act as it seeks to regulate modern slavery in global supply chains.

\section{Findings and Analysis}

\section{The UK Modern Slavery Act and Supply Chain Transparency}

We commence our analysis by discussing different aspects of the limitations of the UK Modern Slavery Act. We, in particular, provide narratives of anti-slavery activists as a part of a critical analysis of the Act's attempts to eliminate modern slavery and ensure justice to less privileged groups (this being workers in developing nations) in global supply chains. A summary of the key findings is presented in Table 2.

\section{Limitations of Purpose and Scope of the Act}

We first consider activists and experts' views on the purpose of the UK Modern Slavery Act of 2015. There are consensus views that the overall aim of the Act is to reduce modern slavery in UK companies' supply chains. Regulatory actors interviewed echoed corporate actors who see the Act as aiming to create a 'level playing field' for reporting on human rights risks, managing reputational risks, and driving change in the internal systems and procedures of organisational culture. Anti-slavery campaign groups in the UK see the Act as a positive development, but its aim is sometimes misunderstood. There is scepticism about whether the requirements by themself could help reduce slavery and forced labour in the domestic and overseas operations of the UK organisations. 'There is confusion because we believe the aim would be to reduce modern slavery and compensate victims, but corporations may have thought that the regulatory aim is to reduce business risk only' (anti-slavery camping actor, 3 ). There is a common view among anti-slavery activists that the Act should cover broader aims than corporations' desire to reduce business risks. There is also a consensus view that activists and civil society groups have played a significant role in the development of the present form of the act (including its purpose). 'If you want to understand the Modern Slavery Act and whatever development behind this so far, you need to understand the roles of the civil society groups and NGOs' (anti-slavery campaign actor, 1). In fact, civil society groups and NGO campaigns for the inclusion of Sect. 54 were emancipatory as their campaigns eventually led the UK government to introduce this section. This suggests, in line with the counter-account/narrative literature (Gallhofer et al., 2006; Vinnari \& Laine, 2017), that civil society groups' voices, to some extent, were heard by the regulator. However, as we will see in the following 


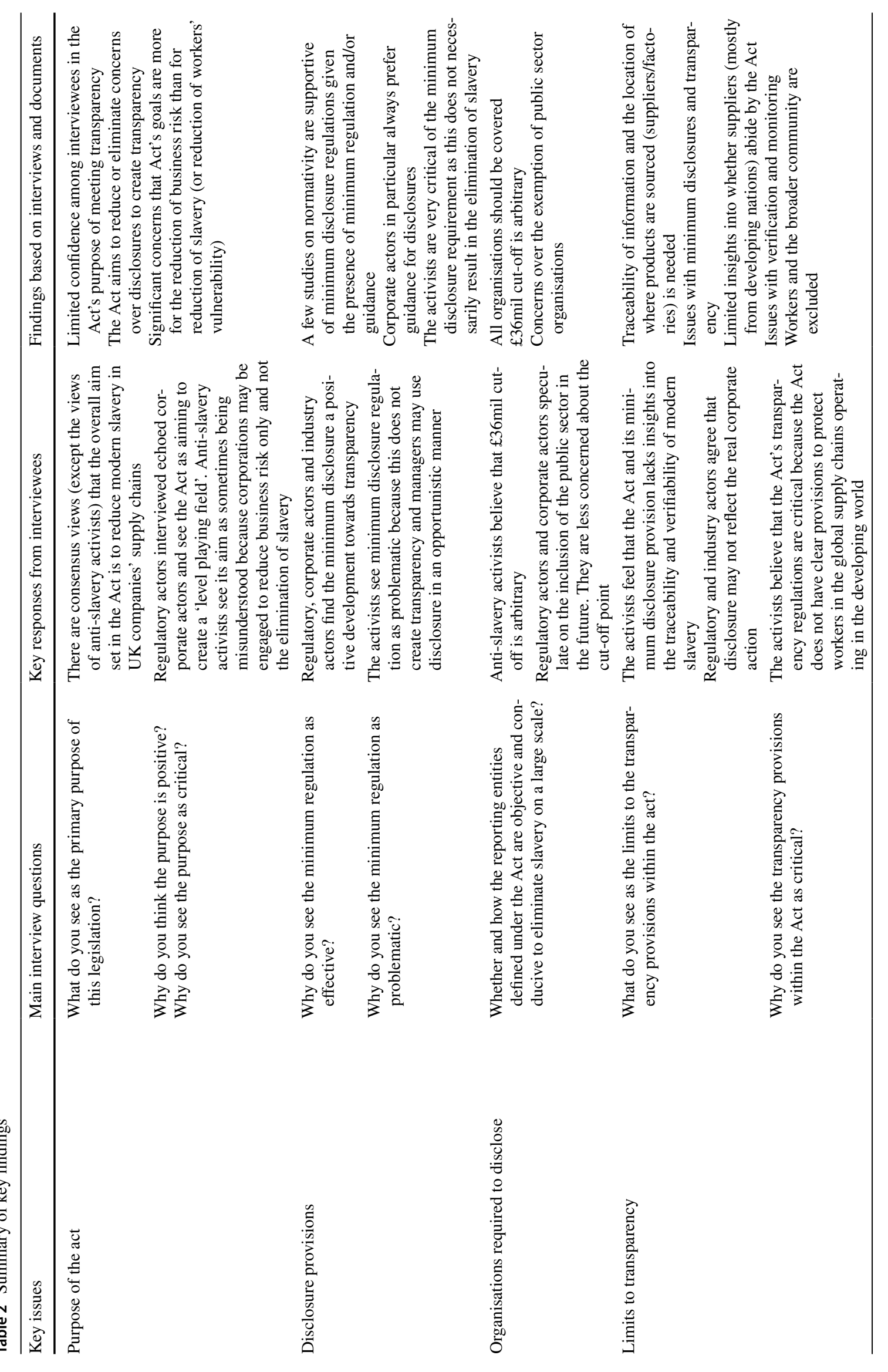




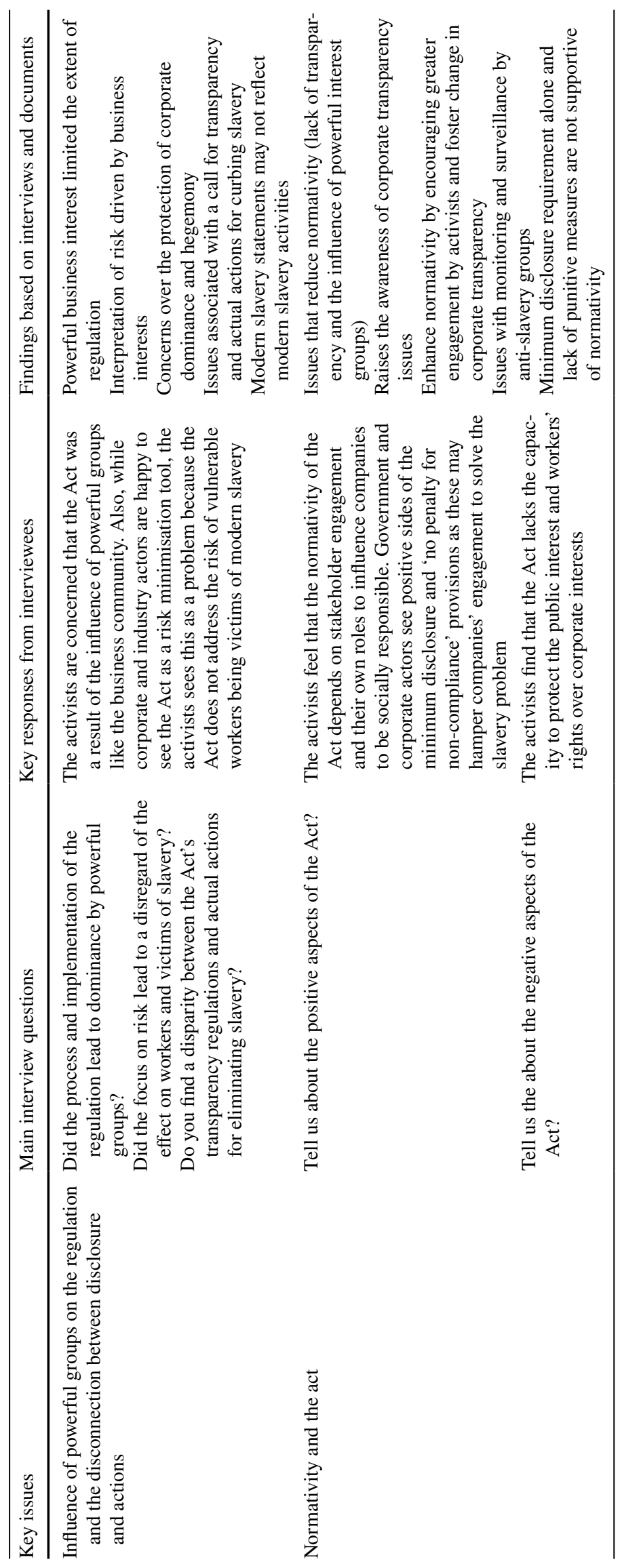


discussions, the anti-slavery activist narrative, as shown by the interviews, revealed that Sect. 54 did not have enough substance, and the resulting change in transparency achieved was therefore limited.

From interviews, we found mixed responses, ranging from a sense that the Act's intention was to extend the elimination of modern slavery (to suppliers in developing nations) to a perception of inherent limitations (since it is merely a reporting requirement). The interviews also revealed diverse views around awareness, uptake and posture among organisations in relation to modern slavery legislation. There is a consistent view among civil society and anti-slavery campaign groups that massive efforts are needed to extend awareness and training to corporate officials and professionals such as lawyers and accountants working for corporations.

While experts representing different stakeholders were generally positive about the perceived aims of the Act, they expressed concern about one provision within the regulation, which requires only organisations that have an annual turnover of $£ 36$ million or above to publish a modern slavery statement each year on their website. Many participants in this study argue that this provision in the Act caps human rights with reference to revenue and that numerous organisations are now not subject to the Act, i.e. there is the suggestion that those with 'an annual turnover below $£ 36$ [million] do not need to care about human rights' (anti-slavery campaign actor, 1). The anti-slavery campaign groups, in particular, find this provision problematic as managers might try to find a way to avoid their responsibilities. One group member told us 'the cap may justify non-reporting companies' increasing levels of human rights negligence in their supply factories located in many developing nations' (antislavery campaign actor, 2). There is also a view that the $£ 36$ million cap was rather strange, and many people wonder where this figure came from.

Another problematic aspect of the Act is that it exempted public sector organisations from publishing modern slavery statements. Many government bodies (from healthcare to defence bodies) source some or all the products they require from suppliers in developing nations but are not covered under this Act. ${ }^{6}$ From a transparency perspective, if the aim is to create transparency, the revenue cap and the exclusion of the public sector from the reporting requirements appear to hinder the achievement of transparency at a broader level.

\footnotetext{
${ }^{6}$ In the Modern Slavery independent review interim report, the experts suggested that like the Australian Modern Slavery Act of 2018, the UK Government should extend Sect. 54 of the Act and include reporting obligations for the UK public sector (Home Office, 2019). At the time of the revision of this article, we found that in line with experts' recommendations and civil society concerns, the UK government has now suggested that public sector organisations (including ministerial departments in England and Wales-Scotland and Northern Ireland are considered separately) will be required to
}

\section{Limitations of the Minimum Disclosure Provisions}

The UK Modern Slavery Act 2015 suggests that relevant companies disclose whatever plans and actions they have put in place to curb modern slavery. Interviewees shared a concern over the minimum disclosure provisions of the Act. This remains effectively optional for organisations since if a company simply states that 'it does not have any slavery in its entire operations, it meets the regulatory compliance' (anti-slavery campaign actor, 1). 'Nowhere in the regulation clearly mentions [that] any information provided needs to be verified externally' (independent supply chain auditor and anti-slavery campaign actor, 6).

While minimum disclosure requirements can be a sensible early step for many organisations, the activists we interviewed expressed serious reservations that the disclosure provisions do not achieve the stated aim of the Act (i.e. the elimination of modern slavery), and there is no legal accountability associated with the disclosures. While the Act requires a senior manager (CEO, director or general manager) to sign the report, we found some uncertainty among interviewees about whether minimum disclosure requirements would help much in terms of holding the signatory accountable. Where a director or senior manager signs off a modern slavery statement, her/his responsibility is unclear, i.e. their accountability is reduced to the minimum disclosure requirements. A big question remains: 'if a CEO signs a report with minimum information like "our company does not have any slavery in its entire operations", does it really release [the] CEO's responsibility and accountability to a greater extent?' (anti-slavery actor, 1). There is also a view that the minimum disclosure requirements do not require companies to provide detailed and factual information to the wider community (anti-slavery campaign actor, 2).

In addition, there are concerns about the government's lack of initiative regarding the recording and availability of modern slavery report submissions. There should be a modern slavery registry mechanism through which the public can view submitted modern slavery statements with relative ease. $^{7}$

Interviewees share concerns that the minimum disclosure provisions under Section 54 give organisations discretion to disclose or not to disclose whatever they want to disclose or not. While this has some advantages, there is a broader

\section{Footnote 6 (continued)}

produce modern slavery statements from 2021 (see, https://www.gov. uk/government/news/new-tough-measures-to-tackle-modern-slaveryin-supply-chains).

${ }^{7}$ In response to broader stakeholder concerns, on 11 March 2021 the UK government launched a 'modern slavery statement register online' and it "strongly" encourages concerned organisations to submit their most recently published modern slavery statement to the register to show what they have reported. However, this is still vol- 
concern that regulators may not be able to hold organisations accountable, given that many organisations do not apparently care about slavery practices in their supply chains. 'Through the minimum disclosure requirement [it appears] as if the entire transparency is reduced to [the] "disclosure" provision of the Act' (policy advisor, professional accounting body). Past studies have revealed a level of concern about the effectiveness of the minimum disclosure requirements (Chilton \& Sarfaty, 2017; Nolan, 2017; Phillips, 2015). Our findings are therefore consistent with the past research in this regard. However, there are studies that focus on the normativity of social and environmental disclosure regulations that found that minimum or low legal requirements and global norms/guidelines such as the GRI, may prompt the achievement of normativity (Chelli et al., 2018). At the same time, Chelli et al. (2018) suggest that minimum requirements, while achieving normativity, may not create transparency. We argue that minimum disclosure requirements may not create transparency if civil society or activist groups do not put pressure on companies to be socially accountable. We also argue, in line with the literature on alternative accounts (Islam et al., 2018, 2020; Gallhofer et al., 2006), that the narratives of anti-slavery activists need to be mobilised to create change in corporate accountability and transparency within global supply chains.

There is a consensus view that 'ensuring transparency is one of the key aims of the UK Modern Slavery Act' (retail industry association leader). While political leaders express the same view when talking about the UK Modern Slavery Act, many may not be aware that the minimum disclosure provision (as discussed previously), may jeopardise transparency. A few industry experts stated that 'the act was a positive development of transparency' (policy advisor, professional accounting body), but the anti-slavery activists were concerned about the possible gap between disclosure and actual action - 'I am concerned about how due diligence works or what is actually happening on the ground. There is a disparity between disclosure and what is happening on the ground' (senior anti-slavery campaign actor, 2).

\section{Lack of Traceability, Verifiability and Transparency to the Broader Community}

While a few global retailers disclose supplier information (including factory locations), interviewees expressed mixed views about the traceability of factory locations. Surprisingly, one British retail company that was recently ranked among the top three modern slavery statement producers by

\section{Footnote 7 (continued)}

untary (see, https://www.gov.uk/government/news/government-launc hes-modern-slavery-statement-registry). a global consultancy firm stated that it does not disclose factory locations, as to do so would impact negatively on their competitiveness. As their representative stated, 'while we have been one of the best modern slavery statement providers this year, our statement is comprehensive and detailed; however, we maintain a fair level of privacy regarding disclosing our suppliers' information for our competitive advantage' (ethical trading manager, retail company). Such an approach indicates inadequate transparency and also calls into question the assessor (consultancy) firms that rank companies' best practice reporting. Those who assess modern slavery statements should not disregard the issue of traceability of factory locations within global supply chains (Egels-Zandén \& Hansson, 2016; Egels-Zandén et al., 2015). While traceability is just one aspect of transparency, this could be a good starting point for ensuring transparency to the broader community - some global companies, such as Nike, disclose factory locations worldwide. However, invoking confidentiality and/or competitive advantage, many retailers do not disclose their factory locations. Doing so prompts the question of what competitive advantage a company gains by hiding the location of the factories it uses? This appears to be a major barrier to tackling modern slavery within global supply chains. Anti-slavery activists are concerned over retailers' use of 'hidden factories' with no record of their factory human rights conditions (anti-slavery actors, 1 and 3). While the Act is, to some extent, helpful in the sense that retailers have to publish modern slavery statements, it does not have the scope to locate 'hidden factories' that retailers may have used (anti-slavery actor 3 ). In this context, the news media and NGO counter-accounts have played an important role in exposing poor working conditions in manufacturing (Islam et al., 2018) and related ethical concerns within global supply chains (Islam et al., 2021).

Along with traceability, verifiability or monitoring is crucial to achieving transparency within global supply chains. Verifiability has two aspects - how to verify what organisations say in their modern slavery statement, and any external or independent auditor checks of modern slavery practices in their supply chains. Concerns were expressed that both aspects are disregarded in the Act. One member from an anti-slavery campaign group (2) stated, 'monitoring and enforcement should be a big issue of [the] Modern Slavery Act. Lack of transparency comes from a lack of monitoring and sanctions, which in turn does not produce good results.' The problem with the existing transparency mechanisms is that in the absence of regulatory requirements on verifiability, organisations only respond when they run into trouble when human rights negligence is exposed through NGO and activist narratives (Islam et al., 2021). As an activist (antislavery campaign actor, 3) puts it, 'lots of focus is related to writing the statement. But in my view, the activity behind the statement such as the due diligence process, audit and 
monitoring supply factories, etc. is important. I am not sure how this can be changed over time.'

Extant research (see, for example, Islam et al., 2018) has looked at social compliance audit practices within global supply chains and found tension surrounding the ability of an audit (given its nature) to create accountability to workers. They also found that companies only use independent or third-party auditors when faced with crises (such as the Rana Plaza incident or associated media concerns). The interviewees hold a pessimistic view of existing audit practices, expressing anxiety that as the Act includes no regulatory penalty or sanction, organisations' audit or monitoring exercises remain light. 'I am doubtful that companies following the Act would use an independent audit in the supply chains just to make sure there is no slavery in the chains' (anti-slavery campaign actor, 7). Past research has revealed that transparency and disclosure are crisis-led and retailers usually respond to supply chain-related legitimacy crises highlighted by news media with positive disclosures (Islam \& Deegan, 2010).

There is also a concern that workers' or victims' voices would remain unheard. 'The Act does not empower workers and victims of modern slavery as there is no mechanism for workers to follow the Act and get remedy if they are victims' (anti-slavery campaign actor, 7). 'At the grass-root level, workers do not know who is buying the goods and, given that some people may argue that workers have a right to know whose products they are producing, that is why we need to see transparency in the entire production process' (independent supply chain auditor and anti-slavery campaign actor, 6).

\section{Domination by Powerful Interests}

Domination by powerful corporate interests could be partly responsible for many of the failures of transparency. The central goal of the Modern Slavery Act, the assumption of transparency, has somehow been constrained or influenced (captured) by corporate interests and corporate risk management strategy. From the broader community perspective, this is problematic, since they see managers as far more concerned about business risk than the risk to the community. 'To us, reporting is an important part of our risk management strategy' (CEO, civil contract association). Anti-slavery campaign organisations are concerned about the interpretation of the risks of modern slavery by corporate management as a risk management strategy. One director of an NGO (anti-slavery campaign actor, 1) stated:

The legislation talks about the risks of modern slavery, so of course, that would mean how do business operations create the risk of modern slavery and human trafficking. Do business operations deal with people who are having a vulnerability, such as migrant workers, women workers, etc.? Does a company operate in remote locations where people cannot see what is going on? Does a company source product from a supplier in a country with the vulnerability of modern slavery? All of those things create the risk of slavery and human trafficking. That's the way we think about risks. The way that the vast majority of businesses think about risk is 'what if it's a risk to my business, to my production or to my profit'. There is a tiny handful of companies that are now beginning to understand risk from the broader way than their own perspective, but there is a very long way to go before the majority [of] companies get that. There is a long way for businesses to realise people were victims of modern slavery.

A follow-up interview with an anti-slavery campaign actor has a similar view:

Whose risk? The risk to the business and not to the society and the environment? If the Modern Slavery Act is only a part of a manager's risk management strategy and not for eradicating slavery, we need to have a big say!

Their view is that the application of the Modern Slavery Act is problematic because it mainly protects industry interests while victims' interests and voices remain unheard. In other words, it contains no strong provision stating that workers' interests are directly protected by the Act. Most importantly, supply chain complexities favour corporations over suppliers and workers. The complexities create a favourable position for powerful groups (Carpenter \& Moss, 2013), leading to compromises with business by, for example, not imposing stringent requirements, such as for the independent audit of labour rights.

The regulatory process is a political process in which power struggles occur, and powerful actors dominate and influence regulation for their own protection (Dal Bó \& Di Tella, 2003; Etzioni, 2009; Wilson et al., 2018). Given that, one should not expect the process of formulating the Modern Slavery Act to be neutral or objective. One anti-slavery activist (anti-slavery campaign actor, 5) stated "while the Act remains the reflections of civil society organisations, the way [the] Act was created, and in particular, the way the regulation came up as a minimum disclosure requirement, was a result of the influence of powerful groups like a business community'. Another activist stated, 'Who created weak regulation? Well, you need to understand there was a political lobby... Companies feel it is costly for the compliance and they do not want any mandatory requirements and penalty provision in case of non-compliance' (anti-slavery campaign activist, 4). 
It has also been observed that a large number of companies are not subject to the Act, and neither is the public sector. One activist (anti-slavery campaign, 1) stated that 'you need to understand, the lobbies started even before the Parliamentary bill was placed, a large number of business members and industry groups perhaps lobbied the government to be excluded from the requirement'.

The literature also highlights broad community concerns at how favourable the position is for organisations. LeBaron and Rühmkorf (2019, p.738), quoting from an interview, claimed that 'there's a lot of unwarranted excitement around transparency. Every company has slavery in their supply chain - anyone who says they don't is lying or incompetent... Transparency legislation won't do anything to change that'. A global law firm claimed that there is a fundamental flaw in the Act 'as in reality, organizations could simply state that no precautions have been taken to ensure their organization is free of slavery and this would be accepted as a compliance. ${ }^{8}$

During the early stages of implementing a law, the regulator was either genuinely optimistic or at least prepared to deploy persuasive arguments for the possible success of the regulation. As the UK's Prime Minister Theresa May stated, during the early stages of regulatory compliance:

The first legislation of its kind in Europe, this act... has delivered enhanced protection and support for victims and a world-leading transparency requirement on businesses to show that modern slavery is not taking place in their companies or their supply chains... But we must not stop there. Just because we have some legislation does not mean that the problem is solved. So as Prime Minister, I am setting up the first-ever government task force on modern slavery (UK Government, 2016, cross reference, Bloomfield \& Lebaron, 2018).

Despite such persuasive language by the Prime Minister, the broader concerns over regulatory capture are now more visible than before. At present, the regulation is regarded as doing more to serve large corporate interests than it does to address the suffering of vulnerable workers employed along global supply chains (Bloomfield \& Lebaron, 2018). In 2018, the UK's first-ever Independent Anti-Slavery Commissioner, Kevin Hyland, who had been appointed by the Prime Minister, resigned while citing government interference in his role (Dearden, 2018). Despite stating 'the law guarantees the independence of the Independent Antislavery Commissioner, who is responsible for improving the prevention, detection, investigation and prosecution of slavery and human trafficking offences' (Dearden, 2018), in his resignation letter Kevin Hyland 'conceded failures over

\footnotetext{
${ }^{8}$ Squire Patton Boggs (2015)
}

the lack of conviction of criminals, inadequate support for slavery victims, and limited action from businesses to tackle the problem' (Ford, 2018). It appears that interest groups have captured the regulation in a way that prevented the Anti-slavery Commissioner from working independently to curb modern slavery. This evidence is consistent with how regulatory capture is defined within the diverse literature (Levine \& Forrence, 1990; Hantke-Domas, 2003; Baudot et al., 2017; Dal Bó \& Di Tella, 2003; Hines, 1991; Paisey \& Paisey, 2012).

\section{Apparent Disconnection Between Anti-Slavery Disclosure and Actual Action}

Previous research that examined transparency found a 'transparency fallacy' in global supply chains (Gold \& Heikkurinen, 2018). Claimed transparency may not lead to socially responsible behaviour (Gold \& Heikkurinen, 2018). Following the analysis of the limits of the Modern Slavery Act, it can be argued that, without substantive disclosure and sanction provisions within the Act, any call for transparency may not improve working conditions in supply chains. Such scepticism is encouraged by research into transparency and accountability in relation to the working conditions within global supply chains (e.g. Islam et al., 2018).

One member from an anti-slavery campaign group (actor, 1) expressed concern that (obviously) disclosure is not the same as performance and there are no basic processes set in place to monitor this. Even if processes are introduced, the question of how to implement this in the different countries from where organisations source their products remains. From this interviewee's perspective, it is certainly questionable whether the Act is effective in curbing slavery and unethical practices and protecting human rights. There was general concern over how disclosure can be connected to the activities (if any) towards the elimination of modern slavery. Requiring corporations to disclose, rather than to act, in the hope that greater transparency and disclosures about organisations' activities will foster improvement in working conditions may be misdirected. Prior research in accounting showed that the voluntary nature of social disclosure had the effect that social disclosures often do not reflect the real actions and disclosure can be used to maintain the existing hegemony and inequality as exposed through counter-narratives by NGOs, civil society organisations and the media (Semeen \& Islam, 2021; Islam et al., 2021). Similarly, critical accounting research on transparency also found that transparency through corporate disclosures can be problematic (see, for example, Coslor, 2016; Roberts, 2009). The apparent disconnection between antislavery disclosures and real actions by corporations, may relate to the literature on organisational decoupling that suggests that organisations may decouple their institutional 
practices (such as disclosures practices) from their actual organisational actions (Aguileraet al., 2007; Holder-Webb \& Cohen, 2012; Jamali, 2010; Lepoutre \& Valente, 2012; Sandholtz, 2012). Drawing on this literature, we argue that the UK Modern Slavery Act creates a context within which corporations' decoupling via modern slavery disclosure appears to be ceremonial or symbolic — which may render a form of institutional 'immunity' to regulatory pressures (Lepoutre \& Valente, 2012). However, we do not rule out the importance of a particular disclosure regulation if such regulation contain substantive provisions for the companies to be socially accountable.

\section{Critical Factors in the Creation of Normativity of the UK Modern Slavery Act}

While prior normativity research often found that regulations via external guidance, standards, and codes led to the creation of normativity (Buhmann, 2011; Chelli et al., 2018; Manacorda, 2014), we argue that more research is necessary to support or challenge these findings and interpretation. A problem (which prior normativity research did not address) arises when minimum compliance or disclosure requirements do not create transparency. Critical factors in the creation of normativity of the Act are presented next.

\section{Awareness Building Efforts and the Need for Broader Stakeholder Engagement}

For many, the Act's normativity seems to lie in it being a starting point for dialogue, launching sensible conversations and actions focussed on modern slavery. Several anti-slavery activists observed that the Act has a long-term role to play, including raising awareness and creating transparent corporate practices in relation to modern slavery. In particular, many argue that the Act stimulates awareness of corporate transparency about modern slavery within business operations, including supply chain operations. Some also believe the Act is a part of efforts to raise global awareness of modern slavery. One anti-slavery campaign actor (3) stated the 'good thing is this [is] a part of a global movement: Australia has come up with an Act [Modern Slavery Act 2018], Germany is coming forward and other countries [are] coming... this [is] a wide range of global awareness'. The Act creates the necessity for awareness-building collaborations among professional groups. There is consensus among anti-slavery activists about the need for corporations to collaborate with NGOs and anti-slavery campaign organisations on training and raising awareness around assessing and tackling modern slavery risks in supply chains. One of our interviewees, a senior official from a UK-based accounting professional body, observed that since accountants and auditors are usually engaged in producing organisational disclosures and assurance practices, the Modern Slavery Act regime has implications for the profession. Accordingly, his organisation is collaborating with civil society and human rights bodies to run awareness-building training sessions and workshops for accountants and auditors. There is also a common view among interviewees that modern slavery is a multidisciplinary issue, and it is expected that collaborations among different professional and non-professional groups - including accountants/auditors, lawyers, business executives, consultants, trade unions, labour rights activists and other civil society groups - will emerge to create corporate accountability in relation to modern slavery.

The normativity of the Act depends on how regulators in a democratic society encourage greater engagement by civil society actors to produce counter-narratives (Gallhofer et al., 2006; Semeen \& Islam, 2021), and foster change in corporate transparency. Anti-slavery activists interviewed believe that the UK Modern Slavery Act does enhance the scope for NGOs, activist groups, and civil society organisations to monitor corporate behaviour and collaborate with the business to solve the issues (i.e. Islam \& Van Staden, 2018). One interviewee (anti-slavery campaign actor, 4) provided an interesting insight: 'following the Act, several civil society organisations [have] come up with reporting and evaluations or their scores against companies' modern slavery transparency so that the concerned companies do not want to see bad scores in the future. Several other civil society organisations directly engage and collaborate with the business to tackle modern slavery'. An anti-slavery campaign actor (1) who is pushing the government for legislation that holds companies accountable stated 'we are active to hold companies liable for modern slavery, we are wanting government [to] take some solid action. A new Modern Slavery Act review has been released last week and you can see some of our recommendations. Our key recommendation is to move towards monitoring and sanctions'. An ethical investor regards the Act as helping to monitor companies in the public domain: 'our monitoring efforts (which also depends on NGOs) is slow, but it is moving in a positive direction. The Act is helpful to monitor and score companies in terms of human rights. If you look at pension funds (larger 
funds), we are concerned about the modern slavery issue because pension funds should be socially responsible...'

At the implementation stage of the Act, NGOs' or campaign groups' roles are crucial. Some anti-slavery campaign organisations have started ranking companies in terms of the quality of their reporting. Some companies have been ranked highly for reporting and a few were interviewed. One responded, 'I do not know whether it is best reporting or not, but for sure, we have improved our quality of disclosures. We have now greater transparency in supply chains' (sustainability manager, UK retail company). From this discussion, we argue that given the minimum disclosure requirements of the Act, the creation of normativity largely depends on NGOs and campaign organisations' continued engagement and collaboration with corporations and regulators. While prior research on normativity found that along with regulation, external guidelines (for example, global guidelines such as the GRI) are a precondition for sustaining normativity (Buhmann, 2011; Chelli et al., 2018; Manacorda, 2014), we provide additional insights that direct or indirect engagement by NGOs and anti-slavery campaign organisations have a greater promise to create normativity. While our research adds to earlier research looking into the attainment of normativity (see Bebbington et al., 2012) and its relationship with disclosures and transparency (Chauvey et al., 2015), we argue that higher levels of normativity can be achieved if NGOs and campaign groups are empowered and emphasise public interest over corporate self-interest.

\section{Conformance with the Act and Broader Community Expectations}

The normativity of regulation also depends on how the regulatory environment encourages regulated (companies) to conform with broader community expectations. Chelli et al. (2018) found that French environmental disclosure regulations and broader community expectations, as reflected by the GRI guidelines, prompted the attainment of normativity. We argue that not only global expectations but also local (country-based) expectations, as reflected in NGO and activist narratives and accounts (Islam et al., 2021), are important contributing factors for the achievement of normativity. Accordingly, as mentioned earlier, some anti-slavery campaign actors stated that the Act partly reflects broader community expectations. This entails a level of normativity as, despite significant limitations, the Act has value or appears relevant to the broader community, including NGOs and activists. As modern slavery statements required by the Act are publicly available on organisations' websites, these are available to consumers, media, NGOs, and investors, i.e. key stakeholders can view them and evaluate them accordingly (anti-slavery campaign actor, 5). When interviewees were asked whether the regulations help to obtain a sense of normativity, a consensus view was expressed. One antislavery campaign actor (4) stated:

Yes, the Act has merit. The Act does make the modern slavery statement publicly available. The more people read the statement, the more serious companies would be to provide objective information. If some people are enquiring whether a company meets the requirement and commenting on this accordingly, it does put pressure on companies to be responsive.

Some participants have addressed the normativity issue by reviewing whether the Act meets the needs of the broader community. They do not think the Act is ideal, but they also think that the Act meets expectations to some extent as it has some social value. As anti-slavery campaign actor (4) stated, 'at least we have something to assess and score companies' compliance [against]'. And interestingly, one manager from an ethical investment company sees a significant advantage of the Act in the following: 'the Act helps us to assess and score companies' modern slavery performance. In line with the Act, we assess the companies' modern slavery statements and provide our score and recommendation to our investee who are eager to invest their money in a responsible manner. I think this matter!

\section{Activist Concerns over the Regulator's Priority to Protect Corporate Interests over the Public Interest}

One of the critical factors that can limit normativity is the regulator's lack of power to protect the public interest. The limits of the transparency provision under the Act and the ongoing influence by powerful interest groups reduce the normativity of the UK Modern Slavery Act. 'There are, of course, some issues that are associated with the demerits of the Act' (anti-slavery campaign actor, 2). 'It is a type of requirement that might encourage companies [to] provide some superfluous disclosure on modern slavery without necessarily engaging in the real change or elimination of slavery' (chief policy advisor, accounting body). Another problem was highlighted: 'it is difficult to compare between two companies even [where] both adopted the modern slavery 
statement. In other words, it is difficult to differentiate good and bad companies because apparently, based on reporting, one may not find any difference. This can be risky for ethical investors' (manager, ethical investment firm).

The regulation setting process is a political process in which the voices of powerful interest groups such as the business community can be prioritised over civil society groups. Accordingly, in relation to the provision of penalties for non-compliance with the Act, the government feared that any provision for injunction or punishment would not be accepted by the regulated and, therefore, might hamper transparency. '[A] punitive approach might hamper transparency... we have not taken an injunction so far because the issue of global supply is so complex' (a government policy advisor). This statement is consistent with prior research on the normativity of regulations that suggested that penalties for non-compliance should not be a necessary precondition of normativity (Chelli et al., 2018). But we argue that it is the dominant business interests that suppressed punitive actions against wrongdoers, which in turn suppress both normativity and transparency. From the interviews and reading around the subject, we detected a sense of resistance from the regulated, i.e. the business community. There is a view among anti-slavery activists that in order to protect the interests of regulated organisations and not the workers or victims, the government perhaps imposed a much more user-friendly form of regulation. 'The Act does not impose any penalty even if a business does not produce any modern slavery statement' (anti-slavery campaign actor, 4 ).

All the critical factors that limit transparency, as discussed in earlier sections, have implications for normativity. As one anti-slavery campaign actor (anti-slavery campaign actor, 4) repeated, 'if a company does not comply with the Act, nothing will happen. But there should be legal demerit to hold companies accountable.' Some of these concerns are antithetical to the notion of normativity as 'the moral bases of legality' (Ewick \& Silbey, 1998). This type of concern, along with variations in corporate responsiveness to the regulations, might lead to the adoption of future punitive tactics, including stringent regulation by regulators themselves (Ayres \& Braithwaite, 1991). It follows then that if certain provisions of a particular regulation are problematic to create transparency, this may also be problematic in the creation of normativity. We discussed earlier that antislavery activists were concerned over the Act's minimum disclosure provisions. While a growing amount of prior research on normativity (Buhmann, 2011; Chelli et al., 2018;
Manacorda, 2014) appeared supportive of minimum disclosure requirements, given that other guidance (i.e. from UN guidelines to the GRI guidelines) played a role in the process of achieving normativity, we find this notion problematic because achieving normativity largely depends on how well stakeholder activism, activist campaigns and social movements were mobilised to create transparency (Islam \& Van Staden, 2018). If the broader community or activist groups do not put pressure upon companies to be socially accountable, minimum disclosure requirements alone may not create normativity. While our insights are not exhaustive, it is important for further research on this issue.

\section{Conclusion}

This article provides essential insights into the views of anti-slavery activists and experts on the UK modem slavery Act of 2015 and its implications in relation to eliminating modern slavery from global supply chains. Most of the interviewees of this study articulated cautious confidence in the Act and its aims to foster corporate transparency and support for the public interest and in the normativity of the Act. For many interviewees, the Act is a starting point for broader dialogue among stakeholder groups to encourage corporate transparency in relation to modern slavery. There is a consensus view that the disclosure provisions of the Act may not help to eliminate modern slavery in the shorter term but may help to build long-term solutions. Other views see the Act as having been influenced by powerful interest groups whose motivations were business risk management rather than minimising the risk of people falling victim to modern slavery in supply chains, mainly operated in developing nations. For many interviewees, the constructive aspect of the Act will be its normativity (Ewick \& Silbey, 2003), which should encourage 'more' scrutiny of regulated organisations by civil society groups and human rights activists.

While the interviewees find the transparency provisions of the UK Modern Slavery Act a persuasive concept, most of them are also sceptical about the way the Act operationalise these. The call for transparency in the Act is restricted by the limited disclosure requirements, limits to the range of entities required to publish modern slavery statements and limited means to hold regulated organisations responsible for their supply chain operations in developing nations. While the call for transparency is an important yardstick to measure corporate responsibility and sustainability (Gold 
\& Heikkurinen, 2018), it has been observed that limited transparency requirements in the Act have led to limited corporate liability and responsibility for tackling modern slavery and unethical labour practices within global supply chains. In particular, the traceability of suppliers and their factory locations is a critical aspect of transparency within global supply chains (Egels-Zandén \& Hansson, 2016; Gardner et al., 2019) that is disregarded in the Modern Slavery Act. Anti-slavery activists believe that the Act has been influenced by corporations and some believe that there is little legal scope to hold organisations accountable for slavery practices. There is a view that the regulation has been captured by powerful corporate groups for their own interests (Baudot et al., 2017; Hantke-Domas, 2003; Hines, 1991; Levine \& Forrence, 1990; Paisey \& Paisey, 2012), and that modern slavery disclosures, therefore, attempt to reduce business risk and do not address and reduce the risks of those falling victim to modern slavery. The interviewees observed that risk minimisation agendas, among both regulators and corporations, may not automatically reduce the severity of modern slavery practices within global supply chains. Although the normativity of the Act can be achieved (Ewick \& Silbey, 2003) through collaboration with, and surveillance activities by, NGOs and anti-slavery activists, the ascendance of corporate self-interest over public interest may hamper normativity. Unlike prior research on normativity (Buhmann, 2011; Chelli et al., 2018; Manacorda, 2014), we argue that the Act's creation of normativity is constrained by NGOs and activists' capacity to mobilise pressures upon companies to be socially accountable. In line with the literature on counter-accounts (Semeen \& Islam, 2021; Lehman et al., 2016; Gallhofer et al., 2006), we argue that the narratives of anti-slavery activists regarding unethical modern slavery practices, play an important role to mobilise pressures upon corporations to follow the Act.

Through close observation of practices under the Modern Slavery Act 2015, we contribute to the current understanding of the limitations of corporate transparency and related regulation. First, we document not only the current limitations of transparency under the Act, but also the issues with relational compliance with the (minimal) disclosure requirements within a supply chain setting. Second, although some researchers provided a theoretical overview of the limits of transparency and accountability (see, for example, Gold \& Heikkurinen, 2018), in this study, we have observed the phenomena through interviews with social and institutional actors who are knowledgeable in the area of corporate responsibility in relation to modern slavery. Third, in line with the literature on counter-accounts/narratives (Gallhofer et al., 2006; Lehman et al., 2016), we observed how particular civil society groups, this being anti-slavery activists, produce narratives regarding the roles of regulators and corporate actors. Fourth, we also contribute to the understanding of regulatory capture by highlighting how businesses seek to minimise their own risk rather than show concern for victims of modern slavery. Finally, we extend the knowledge about normativity (Chelli et al., 2018) by providing new insights into how the normativity of the Act largely depend on the activism and campaigns by NGOs and anti-slavery groups.

We acknowledge that while we problematised transparency limitations of the UK Modern Slavery Act, we mostly relied on the narratives of anti-slavery activists. Our approach is consistent with the counter-account literature (Lehman et al., 2016; Gallhofer et al., 2006; Semeen \& Islam, 2021). Accordingly, we argue that, from a stakeholder/societal point of view, NGOs and social activists are in a better position than profit-driven shareholders or corporate managers to provide views and narratives on the limitations of a particular regulation to create transparency and ethical practices within global supply chains. We also argue that while the expectations of NGOs and social activists may be seen as unrealistic by some corporate managers, these expectations can be emancipatory to the broader community (including the victims of modern slavery within global supply change) and a catalyst for future change in corporate accountability. We encourage further research to investigate the emancipatory roles of different stakeholder groups, including anti-slavery activists, journalists, suppliers and workers, in global supply chains operating in the developing world. Moreover, while existing modern slavery disclosure regimes are new and emerging in nature, calling on corporations to disclose rather than to act and the idea that greater transparency and disclosures about organisations' activities will foster improvement in working conditions, remains largely under-researched. Along these lines, we also call for more research into new modern slavery disclosure regimes. 


\section{Appendix 1: Information on interviewees}

\begin{tabular}{|c|c|c|}
\hline Positions & Interview timing & Description of experience \\
\hline $\begin{array}{l}\text { Project lead, an anti-slavery and workers' } \\
\text { rights organisation }\end{array}$ & 20th Nov 2018, 10-10.45 am & $\begin{array}{l}\text { Leading a project on human rights in the supply } \\
\text { at a major global business and human rights } \\
\text { NGO }\end{array}$ \\
\hline $\begin{array}{l}\text { Head of sustainability policy, a UK retail } \\
\text { association }\end{array}$ & $\begin{array}{l}25 \text { th Nov } 2018 \\
12.30-1.10 \mathrm{pm}\end{array}$ & $\begin{array}{l}\text { Co-chairing modern slavery strategy and imple- } \\
\text { mentation group - Transparency in supply } \\
\text { chains at a major retail association in the UK }\end{array}$ \\
\hline $\begin{array}{l}\text { Lead ethical and responsible investment } \\
\text { engagement, Ethical investment firm }\end{array}$ & 17th January 2019, 3-4 pm & $\begin{array}{l}\text { Working as a research expert on modern slavery } \\
\text { at the UK's major charity fund management } \\
\text { firm }\end{array}$ \\
\hline $\begin{array}{l}\text { Head of slave-free business development, } \\
\text { Anti-slavery campaign organisation }\end{array}$ & 25th January 2019, 10-11.30am & $\begin{array}{l}\text { Leading the business development at a UK } \\
\text { modern slavery NGO that is directly engaged } \\
\text { with businesses to tackle modern slavery }\end{array}$ \\
\hline Director, an ethical investment firm & 17th January $2019,9.30-10.15$ am & $\begin{array}{l}\text { Senior director of shareholder advocacy at a } \\
\text { major religious-based investment services } \\
\text { company }\end{array}$ \\
\hline $\begin{array}{l}\text { Director, slave-free supply chains, Anti-slav- } \\
\text { ery campaign organisation }\end{array}$ & 10th December 2018, 9.45-10.15 am & $\begin{array}{l}\text { Independent supply chain auditor and a director } \\
\text { of a UK modern slavery NGO that is directly } \\
\text { engaged with businesses to tackle modern } \\
\text { slavery }\end{array}$ \\
\hline $\begin{array}{l}\text { Head of modern slavery prevention, UK } \\
\text { Government }\end{array}$ & 28th January $2019,10.15-10.45$ am & $\begin{array}{l}\text { Leading different UK government projects in } \\
\text { relation to preventing modern slavery }\end{array}$ \\
\hline Ethical trading manager, a UK retail company & 30th November 2018, 10-10.35 am & $\begin{array}{l}\text { Managing ethical compliance, a UK retail } \\
\text { company. S/he was responsible for prepar- } \\
\text { ing a modern slavery statement that was } \\
\text { subsequently ranked by a consultancy firm in } \\
\text { the top } 3 \text { modern slavery statements among } \\
\text { FT100 }\end{array}$ \\
\hline $\begin{array}{l}\text { Senior policy advisor, A UK professional } \\
\text { accounting body }\end{array}$ & 27th November 2018, 10-10.30 am & $\begin{array}{l}\text { Working with a major NGO to run workshops } \\
\text { for members of an accounting professional } \\
\text { body in the UK; also, the author of an article } \\
\text { on the UK Modern Slavery Act } 2015\end{array}$ \\
\hline Director, Anti-slavery campaign organisation & 15th November 2018, 4-4.30 pm & $\begin{array}{l}\text { Responsible for strategy and operations of } \\
\text { major civil society coalition (NGO) on corpo- } \\
\text { rate accountability. Also working for various } \\
\text { business and human rights projects }\end{array}$ \\
\hline $\begin{array}{l}\text { Policy advisor, Anti-slavery campaign organi- } \\
\text { sation }\end{array}$ & 25 January 2019 11-12 pm & $\begin{array}{l}\text { Working for various business and human } \\
\text { rights projects at major civil society coalition } \\
\text { (NGO) on corporate accountability }\end{array}$ \\
\hline $\begin{array}{l}\text { Director and independent auditor, Anti-slavery } \\
\text { campaign organisation }\end{array}$ & 28th November 2018, 10-11.30 am & $\begin{array}{l}\text { Director of an NGO and the independent audi- } \\
\text { tor in UK companies' supply chains operating } \\
\text { in developing countries }\end{array}$ \\
\hline $\begin{array}{l}\text { Modern slavery advisor and auditor, Anti- } \\
\text { slavery campaign organisation }\end{array}$ & 18th December 2018, 3-4 pm & $\begin{array}{l}\text { Working in various modern slavery projects at a } \\
\text { global ethical trading NGO }\end{array}$ \\
\hline $\begin{array}{l}\text { Chief Executive Officer, a UK civil contrac- } \\
\text { tors' association }\end{array}$ & 18th January $2019,10-10.30 \mathrm{am}$ & $\begin{array}{l}\text { Responsible for the operations of an associa- } \\
\text { tion of civil engineering contractors (many } \\
\text { contractors in the UK are engaged in supply } \\
\text { chain activities) }\end{array}$ \\
\hline
\end{tabular}

Acknowledgements The authors would like to thank and acknowledge CPA Australia for partially supporting their data collection.

\section{Declarations}

Conflict of interest There is no known conflict of interest associated with this publication.
Open Access This article is licensed under a Creative Commons Attribution 4.0 International License, which permits use, sharing, adaptation, distribution and reproduction in any medium or format, as long as you give appropriate credit to the original author(s) and the source, provide a link to the Creative Commons licence, and indicate if changes were made. The images or other third party material in this article are included in the article's Creative Commons licence, unless indicated otherwise in a credit line to the material. If material is not included in 
the article's Creative Commons licence and your intended use is not permitted by statutory regulation or exceeds the permitted use, you will need to obtain permission directly from the copyright holder. To view a copy of this licence, visit http://creativecommons.org/licenses/by/4.0/.

\section{References}

Acerete, B., Gasca, M., \& Llena, F. (2019). Analysis of environmental financial reporting in the Spanish toll roads sector. Spanish Journal of Finance and Accounting, 48(4), 430-463.

Aguilera, R. V., Rupp, D. E., Williams, C. A., \& Ganapathi, J. (2007). Putting the $\mathrm{S}$ back in corporate social responsibility: A multilevel theory of social change in organizations. Academy of Management Review, 32(3), 836-863.

Allain, J. (2017). Contemporary Slavery and Its Definition in Law. Contemporary Slavery: Popular Rhetoric and Political Practice, 37-66.

Ansett, S. \& Hantover, J. (2013). Bangladesh factory fires - the hidden dangers of subcontracting" Ethical Corporation Magazine, 5th February. Available from: http://www.ethicalcorp.com/supplychains/bangladesh-factory-fires-E280\%93-hidden-dangers-subco ntracting

Arnold, D., \& Hewison, K. (2005). Exploitation in global supply chains: Burmese workers in Mae Sot. Journal of Contemporary Asia, 35(3), 319-340.

Ayres, I., \& Braithwaite, J. (1991). Tripartism: Regulatory capture and empowerment. Law \& Social Inquiry, 16(3), 435-496.

Barrientos, S., \& Smith, S. (2007). Do workers benefit from ethical trade? Assessing codes of labour practice in global production systems". Third World Quarterly, 28(4), 713-729.

Baier, M. (2016). Social and legal norms: Towards a socio-legal understanding of normativity. Routledge Matthias Baier. https://doi. org/10.4324/9781315609416

Barth, M., \& Schipper, K. (2008). Financial reporting transparency. Journal of Accounting, Auditing \& Finance, 23(2), 173-190.

Baudot, L., Roberts, R. W., \& Wallace, D. M. (2017). An examination of the US public accounting profession's public interest discourse and actions in federal policymaking. Journal of Business Ethics, 142(2), 203-220.

Bauhr, M., \& Nasiritousi, N. (2012). Resisting transparency: corruption, legitimacy, and the quality of global environmental policies. Global Environmental Politics, 12(4), 9-29.

Bebbington, J., Kirk, E. A., \& Larrinaga, C. (2012). The production of normativity: a comparison of reporting regimes in Spain and the UK. Accounting, Organizations and Society, 37(2), 78-94.

Berliner, D. (2014). The political origins of transparency. The Journal of Politics, 76(2), 479-491.

Bernstein, E. (2017). Making transparency transparent: The evolution of observation in management theory. Academy of Management Annals, 11(1), 217-266.

Birkey, R. N., Guidry, R. P., Islam, M. A., \& Patten, D. M. (2018). Mandated social disclosure: an analysis of the response to the california transparency in supply chains act of 2010. Journal of Business Ethics, 152(3), 827-841.

Blacconiere, W. G., \& Northcut, W. D. (1997). Environmental information and market reactions to environmental legislation. Journal of Accounting, Auditing \& Finance, 12(2), 149-178.

Blacconiere, W. G., \& Patten, D. M. (1994). Environmental disclosures, regulatory costs, and changes in firm value. Journal of Accounting and Economics, 18(3), 357-377.

Blitz, B., \& Simic, A. (2019). The modern slavery regime: A critical evaluation. Journal of the British Academy, 7(Supp. 1), 1-34.
Bloomfield, M. \& Lebaron, G. (2018). The UK Modern Slavery Act: Transparency through Disclosure in Global Governance, Sep 2018, E-International Relations, https://www.e-ir.info/2018/ 09/21/the-uk-modern-slavery-act-transparency-through-discl osure-in-global-governance/

Brusca, I., Grossi, G., \& Manes-Rossi, F. (2018). Setting consolidated reporting standards for local government. Public Money \& Management, 38(7), 483-492.

Buell, R. W., Kim, T., \& Tsay, C. (2017). Creating reciprocal value through operational transparency. Management Science, 63(6), $1673-1695$

Buhmann, K. (2011). Integrating human rights in emerging regulation of corporate social responsibility: The EU case. International Journal of Law in Context, 7(2), 139-179.

Bushman, R. M., Piotroski, J. D., \& Smith, A. J. (2004). What determines corporate transparency? Journal of Accounting Research, 42(2), 207-252.

Chalmers, J. (2013). Special Report: How textile kings weave a hold on Bangladesh, Reuters, May, last viewed on May, 2021 at https:// www.reuters.com/article/us-bangladesh-garments-special-reportidUSBRE9411CX20130502?fbclid=IwAR1ukoUa9z3uM X5PODfIvQshtMRNLwplNGFlptPzwFAZcWcA80LUpc1DrU

Carpenter, D., \& Moss, D. A. (Eds.). (2013). Preventing regulatory capture: Special interest influence and how to limit it. Cambridge University Press.

Chauvey, J. N., Giordano-Spring, S., Cho, C. H., \& Patten, D. M. (2015). The normativity and legitimacy of CSR disclosure: Evidence from France. Journal of Business Ethics, 130(4), 789-803.

Chelli, M., Durocher, S., \& Fortin, A. (2018). Normativity in environmental reporting: a comparison of three regimes. Journal of Business Ethics, 149(2), 285-311.

Chilton, A. S., \& Sarfaty, G. A. (2017). The limitations of supply chain disclosure regimes. Stanford Journal of International Law, 53, $1-54$.

Christ, K. L., \& Burritt, R. L. (2018). Current perceptions on the problem of modern slavery in business. Business Strategy \& Development, 1(2), 103-114.

Coates, J. (2007). The goals and promise of the Sarbanes-Oxley Act. Journal of Economic Perspectives, 21(1), 91-116.

Coslor, E. (2016). Transparency in an opaque market: Evaluative frictions between "thick" valuation and "thin" price data in the art market. Accounting, Organizations and Society, 50, 13-26.

Crane, A. (2013). Modern slavery as a management practice: Exploring the conditions and capabilities for human exploitation. Academy of Management Review, 38(1), 49-69.

Dal Bó, E., \& Di Tella, R. (2003). Capture by threat. Journal of Political Economy, 111(5), 1123-1154.

Dearden, L. (2018). UK's first Independent Anti-Slavery Commissioner resigns citing government interference, May 17 Independent, https://www.independent.co.uk/news/uk/politics/modern-slave ry-uk-commissioner-resigns-interference-kevin-hyland-gover nment-a8356601.html

Doorey, D. J. (2011). The transparent supply chain: From resistance to implementation at Nike and Levi-Strauss. Journal of Business Ethics, 103(4), 587-603.

Egels-Zandén, N., \& Hansson, N. (2016). Supply chain transparency as a consumer or corporate tool The case of Nudie Jeans Co. Journal of Consumer Policy, 39(4), 377-395.

Egels-Zandén, N., Hulthén, K., \& Wulff, G. (2015). Trade-offs in supply chain transparency: The case of Nudie Jeans Co. Journal of Cleaner Production, 107, 95-104.

Etzioni, A. (2009). The capture theory of regulations-revisited. Society, 46(4), 319-323.

Ewick, P., \& Silbey, S. (2003). Narrating social structure: Stories of resistance to legal authority. American Journal of Sociology, 108(6), 1328-1372. 
Ewick, P. \& Silbey, S. S. (1998). The commonplace of law: Stories from everyday life. University of Chicago Press.

FEE (2017). Fast Fashion Has Changed the Industry and the Economy, Foundation for Economic Education (FEE), July, last viewed on May, 1, 2021, at https://fee.org/articles/fast-fashion-has-chang ed-the-industry-and-the-economy/

Fenster, M. (2010). Seeing the state: Transparency as metaphor. Administrative Law Review, 62(3), 617-672.

Finel, B. I., \& Lord, K. M. (1999). The surprising logic of transparency. International Studies Quarterly, 43(2), 325-339.

Ford, R. (2018). Anti-slavery tsar Kevin Hyland steps down amid criticism, 18 May, The Times, https://www.thetimes.co.uk/article/ anti-slavery-tsar-attacks-home-office-qrvhlc3bl

Fung, A., Graham, M., \& Weil, D. (2007). Full disclosure: The perils and promise of transparency. Cambridge University Press.

Gadd, D., \& Broad, R. (2018). Troubling recognitions in British responses to modern slavery. The British Journal of Criminology, 58(6), 1440-1461.

Gallhofer, S., Haslam, J., Monk, E., \& Roberts, C. (2006). The emancipatory potential of online reporting: The case of counter accounting. Accounting, Auditing \& Accountability Journal, 19(5), 681-718.

Gardner, T. A., Benzie, M., Börner, J., Dawkins, E., Fick, S., Garrett, R., Godar, J., Grimard, A., Lake, S., Larsen, R. K., \& Mardas, N. (2019). Transparency and sustainability in global commodity supply chains. World Development, 121, 163-177.

Gold, S., \& Heikkurinen, P. (2018). Transparency fallacy: Unintended consequences of stakeholder claims on responsibility in supply chains. Accounting, Auditing \& Accountability Journal, 31(1), 318-337.

Gold, S., Trautrims, A., \& Trodd, Z. (2015). Modern slavery challenges to supply chain management. Supply Chain Management: An International Journal, 20(5), 485-494.

Gray, G. C., \& Silbey, S. S. (2014). Governing inside the organization: Interpreting regulation and compliance. American Journal of Sociology, 120(1), 96-145.

Grigorescu, A. (2003). International organizations and government transparency: Linking the international and domestic realms. International Studies Quarterly, 4(1), 643-667.

Hansard (2019), Modern Slavery Act: Independent Review, House of Commons Hansard, June, 19, Vol. 662 (viewed at: https://hansa rd.parliament.uk/commons/2019-06-19/debates/66FD5FFB2058-4CAE-8B1F-0EC4B2E09041/ModernSlaveryActInde pendentReview)

Hantke-Domas, M. (2003). The public interest theory of regulation: Non-existence or misinterpretation? European Journal of Law and Economics, 15(2), 165-194.

Harnay, S., \& Scialom, L. (2016). The influence of the economic approaches to regulation on banking regulations: a short history of banking regulations. Cambridge Journal of Economics, 40(2), 401-426.

Heard-Lauréote, K. (2007). A transparency gap? The case of European agricultural committee governance. Public Policy and Administration, 22(2), 239-258.

Hines, R. D. (1991). The FASB's conceptual framework, financial accounting and the maintenance of the social world. Accounting, Organizations and Society, 16(4), 313-331.

Holder-Webb, L., \& Cohen, J. (2012). The Cut and Paste Society: Isomorphism in Codes of Ethics. Journal of Business Ethics, 107(4), 485-509.

Hollyer, J. R., Rosendorff, B. P., \& Vreeland, J. R. (2011). Democracy and transparency. The Journal of Politics, 73(4), 1191-1205.

Home Office, (2015). Statutory guidance: Slavery and human trafficking in supply chains: guidance for businesses, Gov.UK, viewed at https://www.gov.uk/government/publications/ transparencyin-supply-chains-a-practical-guide; full report at: https://assets. publishing.service.gov.uk/government/uploads/system/uploads/ attachment_data/file/649906/Transparency_in_Supply_Chains A_Practical_Guide_2017.pdf

Home Office (2019). Independent Review of the Modern Slavery Act 2015 second Interim Report: Transparency in Supply chains, viewed at: https://assets.publishing.service.gov.uk/government/ uploads/system/uploads/attachment_data/file/796500/FINAL_ Independent_MSA_Review_Interim_Report_2_-_TISC.pdf

Hughes, A., Buttle, M., \& Wrigley, N. (2007). Organisational geographies of corporate responsibility: A UK-US comparison of retailers' ethical trading initiatives. Journal of Economic Geography: Transnational Retail, Supply Networks, and the Global, 7(4), 491-513.

International Labor Organization (ILO) and Walk Free Foundation. (2017). Global Estimates of Modern Slavery: Forced Labour and Forced Marriage, ILO and Walk Free Foundation https://www. ilo.org/wcmsp5/groups/public/---dgreports/---dcomm/docum ents/publication/wcms_575479.pdf

Islam, M. A. (2018). Tackling Modern Slavery: What Role Can Accountants Play? Audit \& Assurance, International Federation of Accountants (IFAC), see on this link: https://www.ifac.org/ global-knowledgegateway/audit-assurance/discussion/tacklingmodern-slavery-what-role-can

Islam, M. A., \& Deegan, C. (2010). Media pressures and corporate disclosure of social responsibility performance information: A study of two global clothing and sports retail companies. Accounting and Business Research, 40(2), 131-148.

Islam, M. A., Deegan, C., \& Haque, S. (2021). Corporate human rights performance and moral power: A study of retail MNCs' supply chains in Bangladesh. Critical Perspectives on Accounting, 74, 102163.

Islam, M. A., \& McPhail, K. (2011). Regulating for corporate human rights abuses: The emergence of corporate reporting on the ILO's human rights standards within the global garment manufacturing and retail industry. Critical Perspectives on Accounting, 22(8), 790-810.

Islam, M. A., \& Van Staden, C. J. (2018). Social movement NGOs and the comprehensiveness of conflict mineral disclosures: Evidence from global companies. Accounting, Organizations and Society, 65, 1-19.

Islam, M. A., Deegan, C., \& Gray, R. (2018). Social compliance audits and multinational corporation supply chain: Evidence from a study of the rituals of social audits. Accounting and Business Research, 48(2), 190-224.

Jackson, J. (2018). Norms, normativity, and the legitimacy of justice institutions: International perspectives. Annual Review of Law and Social Science, 14, 145-165.

Jamali, D. (2010). MNCs and international accountability standards through an institutional lens: evidence of symbolic conformity or decoupling. Journal of Business Ethics, 95, 717-640.

Kasperkevic, J. (2016). Rana Plaza collapse: workplace dangers persist three years later, reports find. The Guardian, May 31, https:// www.theguardian.com/business/2016/may/31/rana-plaza-bangl adesh-collapse-fashion-working-conditions.

Kelly, A. (2014). Supermarket giants in Thailand for prawn slavery talks. The Guardian, 30 July https://www.theguardian.com/ global-development/2014/jul/30/supermarkets-thailand-prawnslavery-seafood.

Kim, S., \& Muldoon, C. (2015). The dodd-frank wall street reform and consumer protection act: accomplishments and shortcomings. The Journal of Applied Business and Economics, 17(3), 92-107.

KPMG. (2017). The KPMG Survey of Corporate Responsibility Reporting 2017. viewed at: https://home.kpmg/content/dam/ $\mathrm{kpmg} / \mathrm{xx} / \mathrm{pdf} / 2017 / 10 / \mathrm{kpmg}$-survey-of-corporate-responsibi lity-reporting-2017.pdf 
KPMG. (2008). The KPMG Survey of Corporate Responsibility Reporting 2008. viewed at: http://s3.amazonaws.com/zanran storage/www.kpmg.bg/ContentPages/45691987.pdf

Landau, I., \& Marshall, S. (2018). Should Australia be embracing the modern slavery model of regulation? Federal Law Review, 46(2), 313-339.

Larrinaga, C., Carrasco, F., Correa, C., Llena, F., \& Moneva, J. (2002). Accountability and accounting regulation: The case of the Spanish environmental disclosure standard. European Accounting Review, 11(4), 723-740.

LeBaron, G., \& Rühmkorf, A. (2019). The domestic politics of corporate accountability legislation: Struggles over the 2015 UK Modern Slavery Act. Socio-Economic Review, 17(3), 709-743.

Lepoutre, J., \& Valente, M. (2012). Fools breaking out: the role of symbolic and material immunity in explaining institutional nonconformity. Academy of Management Journal, 55(2), 285-313.

Levine, M. E., \& Forrence, J. L. (1990). Regulatory capture, public interest, and the public agenda: Toward a synthesis. Journal of Law, Economics, and Organization, 6, 167-198.

Lehman, C., Annisette, M., \& Agyemang, G. (2016). Immigration and neoliberalism: Three cases and counter accounts. Accounting, Auditing \& Accountability Journal, 29(1), 43-79.

Malsch, B., \& Salterio, S. E. (2016). Doing good field research: Assessing the quality of audit field research. Auditing A Journal of Practice \& Theory, 35(1), 1-22.

Manacorda, S. (2014). Towards an Anti-Bribery Compliance Model: Methods and Strategies for a "Hybrid Normativity". In Preventing Corporate Corruption (pp. 3-30). Springer.

Mehra, A., \& Shay, K. (2016). Corporate responsibility and accountability for modern forms of slavery. Journal of International Criminal Justice, 14(2), 453-468.

Meijer, A. (2009). Understanding modern transparency. International Review of Administrative Sciences, 75(2), 255-269.

Miles, M. B. \& Huberman, A. M. (1994). Qualitative data analysis: An expanded sourcebook. Sage

Miles, M. B., Huberman, A. M. \& Saldaña, J. (2014). Qualitative data analysis: An expanded sourcebook ( $2^{\text {nd }}$ edition): Sage publications.

Neu, D., Saxton, G., Everett, J., \& Rahaman, A. S. (2020). Speaking truth to power: Twitter reactions to the Panama Papers. Journal of Business Ethics, 162(2), 473-485.

New, S. J. (2015). Modern slavery and the supply chain: The limits of corporate social responsibility? Supply Chain Management: An International Journal, 20(6), 697-707.

Nolan, J. (2017). Business and human rights: The challenge of putting principles into practice and regulating global supply chains. Alternative Law Journal, 42(1), 42-46.

Oxfam (2018). Richest 1 percent bagged 82 percent of wealth created last- poorest half of humanity got nothing. January, last viewed on May, 1, 2021 at https://www.oxfam.org/en/press-releases/ richest-1-percent-bagged-82-percent-wealth-created-last-yearpoorest-half-humanity

Paisey, C., \& Paisey, N. J. (2012). Whose rights? Professional discipline and the incorporation of a (human) rights framework: The case of ICAS. Critical Perspectives on Accounting, 23(1), $17-35$.

Phillips, N. (2015). Private governance and the problem of trafficking and slavery in global supply chains. In Vulnerability, Exploitation and Migrants (pp. 15-27). Palgrave Macmillan, London.

Pinto, J. G. (2009). Transparency policy initiatives in Latin America: Understanding policy outcomes from an institutional perspective. Communication and Law Policy, 14(1), 41-71.

Rahman, M., Khanam, R., \& Absar, N. (1999). Child labor in Bangladesh: a critical appraisal of Harkin's Bill and the MOUtype schooling program. Journal of Economic Issues, 33(4), 985-1003.
Roberts, J. (2009). No one is perfect: The limits of transparency and an ethic for 'intelligent' accountability. Accounting, Organizations and Society, 34(8), 957-970.

Rogerson, M., Crane, A., Soundararajan, V., Grosvold, J., \& Cho, C. H. (2020). Organisational responses to mandatory modern slavery disclosure legislation: A failure of experimentalist governance? Accounting, Auditing \& Accountability Journal, 33(7), 1505-1534.

Rosenfeld, J., \& Denice, P. (2015). The power of transparency: Evidence from a British workplace survey. American Sociological Review, 80(5), 1045-1068.

Roshitsh, K. (2021). U.K. Modern Slavery Act Isn’t Working as Intended, Expert Alleges. WWD, March, viewed on May, 3, 2021 at https://wwd.com/sustainability/business/u-k-modernslavery-act-isnt-working-as-intended-expert-alleges-12347 80434/

Qian, C., Gao, X., \& Tsang, A. (2015). Corporate philanthropy, ownership type, and financial transparency. Journal of Business Ethics, 130(4), 851-867.

Quaak, L., Aalbers, T., \& Goedee, J. (2007). Transparency of corporate social responsibility in Dutch breweries. Journal of Business Ethics, 76(3), 293-308.

Sandholtz, K. W. (2012). Making Standards Stick: A Theory of Coupled vs. Decoupled Compliance. Organization Studies, 33(5/6), 655-678.

Sarat, A., \& Kearns, T. (1993). Law in Everyday Life. University of Michigan Press.

Senn, J., \& Giordano-Spring, S. (2020). The limits of environmental accounting disclosure: Enforcement of regulations, standards and interpretative strategies. Accounting, Auditing \& Accountability Journal, 33(6), 1367-1393.

Schmidt, M. F. \& Rakoczy, H. (2018) Developing an understanding of normativity. The Oxford Handbook of 4E Cognition, pp.685-706.

Semeen, H. \& Islam, M. A. (2021). Social impact disclosure and symbolic power: Evidence from UK fair trade organizations. Critical Perspectives on Accounting, 102182.

Sobik, J. (2020). Five years after the UK Modern Slavery Act, it's time to ramp it up. Anti-Slavery, March viewed on May, 3, 2021 at https://www.antislavery.org/five-years-uk-modernslavery-act/

Squire Patton Boggs. (2015). The Modern Slavery Act 2015: 10 Key Points for Businesses - What is this New Disclosure Obligation? Available at: https://www.globalsupplychainlawblog. com/files/2015/09/20453-Modern-Slavery-Act-Alert.pdf (Last Accessed: 30/09/2018)

Steiner-Dicks, K. (2019). We know most global companies have modern slavery in their supply chains. Ethical Corporation, August, 6, viewed at: http://www.ethicalcorp.com/ we-know-most-global-companies-have-modern-slave ry-their-supply-chains

Steinfield, C., Markus, M. L., \& Wigand, R. T. (2011). Through a glass clearly: Standards, architecture, and process transparency in global supply chains. Journal of Management Information Systems, 28(2), 75-108.

Stevenson, M., \& Cole, R. (2018). Modern slavery in supply chains: A secondary data analysis of detection, remediation and disclosure. Supply Chain Management: An International Journal, 12(3), 81-99.

The Barrister (2019). Modern Slavery Legislation: companies should not ignore the possibility of UK suppliers as a modern slavery risk. Sep 2, The Barrister, viewed at http://www.barristerm agazine.com/modern-slavery-legislation-companies-shouldnot-ignore-the-possibility-of-uk-suppliers-as-a-modern-slave ry-risk/ 
The Global Slavery Index (2018). United Kingdom, 2018 Slavery Index, viewed at https://www.globalslaveryindex.org/2018/ findings/country-studies/united-kingdom/

Turner, R. J. (2016). Transnational supply chain regulation: Extraterritorial regulation as corporate law's new frontier. Melbourne Journal of International Law, 7, 188-209.

The Guardian (2015). The UK's new slavery laws explained: what do they mean for business? Dec 14, Viewed at: https://www.thegu ardian.com/sustainable-business/2015/dec/14/modern-slaveryact-explained-business-responsibility-supply-chain

UK Government. (2016). Defeating modern slavery. article by Theresa May, Home Office, viewed at https://www.gov.uk/gover nment/speeches/defeating-modern-slavery-theresa-may-article
Wilson, C. E., Morrison, T. H., Everingham, J. A., \& McCarthy, J. (2018). Capture and crush: Gas companies in the fracking dispute and deliberative depoliticization. Geoforum, 92, 106-116.

Zhu, K. (2004). Information transparency of business-to-business electronic markets: A game-theoretic analysis. Management Science, 50(5), 670-685.

Publisher's Note Springer Nature remains neutral with regard to jurisdictional claims in published maps and institutional affiliations. 